\title{
Surface water quality monitoring of an agricultural watershed for nonpoint source pollution control
}

\author{
D.D. Poudel
}

\begin{abstract}
Water pollution is a major environmental problem in the United States. To improve the surface water quality of the 2,493 ha $(6,160 \mathrm{ac})$ Coulee Baton watershed in Louisiana, a collaborative nonpoint source pollution control study was initiated in 2004. Conservation measures and best management practices (BMPs) including cross-fencing of pasturelands

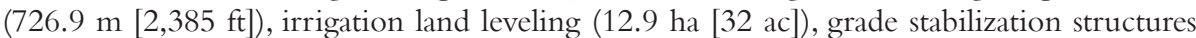

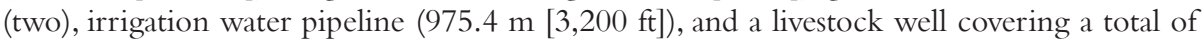
92.7 ha $(229 \mathrm{ac})$ of agricultural land, and repair or replacement of 80 septic systems in the watershed were voluntarily implemented by landowners and homeowners. Water samples were collected from seven monitoring sites for 66 rain events from September 24, 2009, to August 9, 2011. Laboratory determinations of water samples included total suspended solids (TSS), total dissolved solids (TDS), total solids (TS), five-day biological oxygen demand $\left(\mathrm{BOD}_{5}\right)$, nitrate/nitrite-nitrogen $\left(\mathrm{NO}_{3} / \mathrm{NO}_{2}-\mathrm{N}\right)$, soluble reactive phosphate (SRP), total phosphorus (TP), total Kjeldahl N (TKN), chloride $(\mathrm{Cl})$, fluoride $(\mathrm{Fl})$, sulfate $\left(\mathrm{SO}_{4}\right)$, and fecal coliform counts. Surface water temperature, dissolved oxygen (DO), turbidity, conductivity, and $\mathrm{pH}$ were determined in the field using YSI Sonde (YSI Incorporated, Yellow Springs, Ohio). For the watershed, $\mathrm{DO}, \mathrm{BOD}_{5}$, and TS concentrations and fecal coliform count ranged, respectively, between 1.2 and $14.1 \mathrm{mg} \mathrm{L}^{-1}$ (ppm), 2 and $40.1 \mathrm{mg} \mathrm{L}^{-1}, 35$ and 5,719 mg $\mathrm{L}^{-1}$, and $400 \times 10^{6}$ and $17 \times 10^{6}$ most probable number $(\mathrm{MPN})$ per $100 \mathrm{~mL}$. The months of March, April, June, and September showed, on average, higher concentrations of TS and TDS, fecal coliform count, $\mathrm{NO}_{3} / \mathrm{NO}_{2}-\mathrm{N}$, and SRP and TP, respectively. As compared to the ongoing BMPs, the post-BMPs, TSS, $\mathrm{NO}_{3} / \mathrm{NO}_{2}-\mathrm{N}$, SRP, and $\mathrm{BOD}_{5}$ concentrations, on average, were lower by $56.2 \%, 23.1 \%, 82.5 \%$, and $27.4 \%$, respectively. Developed land use types and the failed septic systems were identified as major sources of fecal coliform pollution. These results suggest comprehensive strategies are necessary for effective nonpoint source pollution control in agricultural watersheds.
\end{abstract}

Key words: best management practices (BMPs) — fecal coliform counts-land use typesnonpoint source pollution — septic systems-water quality

Surface water quality impairment due to nonpoint source pollution is a major environmental problem in Louisiana and elsewhere in the United States. Soil erosion from agricultural lands (LDEQ 2000; LSU AgCenter 2012; Poudel et al. 2013), effluents from rice (Oryza L.)/crawfish field ponds (Bollich and Feagley 1994; Orellana and Romaire 2007; Yuan et al. 2007), stormwater runoff from residential areas (Poudel et al. 2010), extreme rain events (Poudel 2006), failed septic systems, point sources, and natural sources are all causes of surface for the month of April and highest monthly average concentrations of total phosphorus (TP) and soluble reactive phosphate (SRP) for the month of September for Bayou Plaquemine Brule watershed in southwestern Louisiana. Similarly, Udawatta et al. (2006) found significantly higher losses of nitrogen $(\mathrm{N})$ in surface runoff between crop harvest in fall and spring planting in Missouri and suggested appropriate vegetative cover to reduce $\mathrm{N}$ losses from agricultural watersheds during the fallow period.

Drainage waters from rice fields in Louisiana have elevated concentrations of sediments, nutrients, and dissolved substances (Bollich and Feagley 1994; Skrobialowski et al. 2004; Yuan et al. 2007) and potentially impair surface water quality downstream. Similarly, the effluents from crawfish ponds, especially during summer months, have high levels of turbidity, TSS, TP, total Kjeldahl N (TKN), dissolved substances, chemical oxygen demand (COD), and organic matter enrichment, causing potential impairment of surface waterbodies downstream (Orellana and Romaire 2007; Yuan et al. 2007). Since low dissolved oxygen (DO) in crawfish ponds is often a serious problem in Louisiana (LSU AgCenter 1999) and some crawfish producers flush their ponds during this hypoxic condition to maintain good water quality (Orellana and Romaire 2007), downstream impacts of such hypoxic water, especially on DO, is possible.

Agricultural wetlands, such as rice fields, crawfish ponds, or rice/crawfish ponds in Louisiana are important habitats for tens of thousands of migratory, wintering, breeding, and resident birds, such as geese, tall herons/egrets, short herons/egrets, white ibis (Eudocimus albus), dark ibises (Pseudibis davisoni), shorebirds, waterfowl, grebes, pelicans, gulls, and cormorants (Huner et al. 2002; Demcheck et al. 2004). Fecal contamination of surface waters from wild birds can be an important factor depending on the abundance of birds and feces production (Kirschner et al. 2004). In fact, several bacterial source tracking studies have identified wild birds and other wildlife, along with domestic animals and humans, as major sources of fecal coliform pollution in surface

Durga D. Poudel is a professor and assistant director of the School of Geosciences, University of Louisiana at Lafayette, Louisiana. 
waterbodies in the United States. Whitlock et al. (2002) studied fecal contamination in the urban watershed of Stevenson Creek in Clearwater, Florida, and reported wild animals, humans, and to a lesser extent dogs as the major sources of fecal pollution in the watershed. Similarly, wild birds, domestic animals, sanitary wastewater from a wastewater treatment plant, and wildlife were identified as the potential sources of fecal coliform contamination in Hampton Harbor, New Hampshire, while waterfowl were identified as the major source of E. Coli contamination in the Lower Boise River watershed in Idaho and fecal coliform pollution of the Four Mile Run watershed in Virginia (USEPA 2002a). American alligators were found as important sources of fecal coliform pollution in South Carolina coastal waters (Johnston et al. 2010), and raccoons and other wildlife were found as major sources of $E$. Coli contamination in the Eastern Shore, Virginia (USEPA 2002a).

Septic systems are major sources of groundwater and surface water fecal pollution in rural coastal areas of the United States (Mallin 2013; Schneeberger et al. 2015). Wastewater contains high level of fecal coliform, pathogens and microbes, total $\mathrm{N}$ (TN), TP, total solids (TS), heavy metals and other chemicals (USEPA 2002b; Chase et al. 2012; Mallin 2013), and a failure of septic systems result in the pollution of both the groundwater and a nearby surface waterbody. The failure of a septic system can generally be distinguished in two main ways: "treatment failure" and "hydraulic failure" (Collick et al. 2006). In "treatment failure," the contaminants are not fully removed before the wastewater enters into a waterbody, while in "hydraulic failure" the wastewater gets ponded in the drained field due to the rise of water table, and the stormwater runoff transports pollutants without further treatment to a nearby waterbody. Improper soil conditions, such as too porous or sandy soils and impermeable or clay soils, high density of septic systems in an area, and lack of regular maintenance of septic systems, are the major factors responsible for septic system failure. Proper maintenance of septic systems is necessary to prevent pollution of surface waterbodies. A general maintenance schedule of a septic system includes regular inspection of the septic system by trained technicians, repair of cracked pipes, tightening of loose nuts and bolts, and the pumping of the septic tank regularly. Failure of septic systems, sew- age discharges, runoff from pasturelands, and stormwater overflows are possible sources of fecal coliform pollution of surface waterbodies in Louisiana (Hill et al. 2006).

Implementation of best management practices (BMPs) on a voluntary basis by landowners has become the major governmental strategy in controlling nonpoint source pollution from agricultural lands in the United States. The BMPs that are commonly implemented for controlling nonpoint source pollution from agricultural lands are related to nutrient management (e.g., regular soil testing), pesticide management (e.g., using GPS for the precision of pesticide application in the field and proper calibration of spray equipment), soil and water management (e.g., filter strips, conservation tillage, and drop structures), pasture management (e.g., streambank protection and livestock watering troughs), irrigation land leveling, grassed waterways, field borders, grade stabilization, and general farm management (e.g., a containment wall for fuel storage tank) (Lowrance et al. 2002; Osmond et al. 2012). Prairie filter strips, riparian buffers, wetlands, swales, and grass filter strips are other conservation measures for nonpoint source pollutant removal from agricultural runoff (Kröger et al. 2012a; Lafrance et al. 2013; Zhou et al. 2014).

Several researchers have evaluated the effectiveness of BMPs for nonpoint source pollution control in the region. Poudel et al. (2010) reported lower median concentrations of TN, TP, nitrate/nitrite- $\mathrm{N}\left(\mathrm{NO}_{3} / \mathrm{NO}_{2}-\mathrm{N}\right)$, and SRP in surface runoff from sugarcane (Saccharum officinarum L.) fields with BMPs compared to those without BMPs, and lower TSS, TN, and $\mathrm{NO}_{3} / \mathrm{NO}_{2}-\mathrm{N}$ median concentrations in surface runoff from pastureland with BMPs compared to those from pasturelands without BMPs in Louisiana. Similarly, Selim et al. (2011) compared rotational and continuous grazing practices in southwestern Louisiana and reported $79 \%$ reduction in sediment loss and 74\% reduction in TP loss from rotational grazing compared to continuous grazing. Kröger et al. (2012b) reviewed scientific literature for the Lower Mississippi Alluvial Valley and reported the nutrient reduction efficiencies of BMPs in the range of $17 \%$ to $76 \%$ for TN and TP.

Despite their effectiveness in nonpoint source pollution control, adoption of BMPs by landowners is often much less than expected for various reasons (Napier and Bridges 2002). In order to enhance the implementation of BMPs for nonpoint source pollution control by landowners, Cockerill et al. (2006) suggested cooperative modeling by involving scientists and the public and developing nonpoint source pollution control strategies as a new planning approach to maintain ecological, social, and economic stability of freshwater resources. On the other hand, White et al. (2009) suggested identification of critical source areas for nonpoint source pollution and the implementation of conservation measures targeting these critical areas in an agricultural watershed for improving surface water quality downstream cost-effectively. Since the effectiveness of BMPs on nonpoint source pollution control is assessed mostly through plot-scale research and the results are generalized at a larger-scale watershed, there is a widespread concern with regard to the precision and the effectiveness of the BMPs in controlling nonpoint source pollution.

The Texas Institute for Applied Environmental Research (TIAER) at Tarleton State University, Texas, through the support of the US Environmental Protection Agency (USEPA) and USDA Natural Resources Conservation Service (NRCS), developed the Planned Intervention Microwatershed Approach (PIMA) for addressing agricultural nonpoint source pollution (Vergura et al. 2002a). The TIAER defines a microwatershed as an area of 1,214 to 8,094 ha $(3,000$ to $20,000 \mathrm{ac})$, with identifiable hydrologic boundaries. According to TIAER, by dealing with these small areas, watershed coordinators can reduce land use variables and more readily identify the sources of pollutant loads. Vergura et al. (2002b) evaluated the effectiveness of the PIMA model for nonpoint source pollution study in the 1,478 ha $(3,652 \mathrm{ac})$ Goose Branch microwatershed in Texas, where the TIAER participated with dairy producers for nonpoint source pollution control using the PIMA approach. Based on this study, for a successful microwatershed intervention, there should be clear policies on the farmers' participation in pollution control issues, such as voluntary as well as regulatory mechanisms for pollution control. Sufficient considerations should also be given for unexpected weather, such as drought and farmers' production decisions, and there should be effective cost-share programs for implementation of the BMPs. 
The specific objectives of this study were to assess (1) spatial and monthly variability of surface water quality and (2) impacts of BMPs and land use types on surface water quality of an agricultural watershed. Results on the spatial and the monthly variability of surface water quality of an agricultural watershed will help scientific communities in further understanding the occurrence, seasonality, and the movement of nonpoint source pollution in agricultural landscapes. Similarly, an understanding of the impacts of BMPs and land use types on surface water quality of an agricultural watershed will help researchers in getting better insights on the practices and techniques of nonpoint source pollution control and water quality improvement. In the region, the knowledge of spatial variability and the seasonality of nonpoint source pollution will help watershed managers, landowners, and other stakeholders to target the major fluxes of nonpoint source pollutants entering into a waterbody while designing and implementing nonpoint source pollution control strategies in the watershed. Similarly, a quantitative assessment of the effectiveness of BMPs in reducing nonpoint source pollutants in an agricultural watershed will help them in adjusting or designing appropriate BMP implementation strategies. Information generated from this kind of investigation will help watershed managers and other stakeholders in the region in developing appropriate watershed management plans for water quality improvement.

\section{Materials and Methods}

Study Area. In order to design and implement a watershed project in southwestern Louisiana, Vermilion Soil and Water Conservation District (VSWCD) led an initiative for building cooperative partnership with landowners and homeowners and other stakeholders in 2004. The cooperating partners in the initiative included Louisiana Department of Agriculture and Forestry, USDA NRCS, Acadiana Resource Conservation and Development (RC\&D) Council, Louisiana Department of Environmental Quality, Louisiana State University AgCenter, Louisiana Cooperative Extension Service, TIAER, University of Louisiana at Lafayette, USDA Farm Service Agency (FSA), Coulee Baton Gravity Drainage District, Vermilion Parish Police Jury, local agricultural enterprises and businesses, and Louisiana Department of Natural
Resources. The Coulee Baton watershed, which is located in the north-central Vermilion Parish in the lower Mermentau Basin of Louisiana (figure 1) and contains $2,493 \mathrm{ha}(6,160 \mathrm{ac})$ mainly in agriculture production, was identified for this study. Major soil series found in the watershed included Crowley silt loam, Mowata silt loam, and Patoutville silt loam. Monthly rainfall for the study area is presented in figure 2 .

Water Quality Sampling, Field Measurements, and Laboratory Determinations. Following a series of stakeholders' meetings and field visits, seven water quality monitoring sites were identified based on water discharge characteristics, land use types, and accessibility (figure 1). Stakeholders' meetings were very helpful in project planning, identification of monitoring sites, identification of water quality parameters for monitoring, as well as coordination of the project activities. Sites 1,2,5, and 7 were on the main drainage channel, while sites 3,4 , and 6 were on the tributaries of the Coulee Baton. Total area and the proportionate areas under each land use type for the seven water quality monitoring sites are presented in table 1 . While rice was the dominant land use type for site 1 and site 7 , sugarcane production was the major land use type for site 3 and site 4. Similarly, in 2011 , site 7 had about $40 \%$ of its total area in crawfish production. Proportion of pastureland for the seven sites during 2009 to 2011 ranged between 0.23 and 0.59. Pastureland was the major land use type for site 2 and site 4. Site 6 had relatively larger proportion of "others (includes developed areas)" land use type compared to the rest of the sites. The proportion of developed land use type for site $6(0.113)>$ site $3(0.06)>$ site $7(0.049)$ $>$ site $5(0.044)>$ site $4(0.035)>$ site 2 $(0.031)>$ site $1(0.028)$.

Each water quality sampling included sampler (ISCO Model 6712, Lincoln, Nebraska) flowmeter (ISCO 4230 Bubbler), tipping bucket rain gauge (ISCO Model 674), 65W $12 \mathrm{~V}$ solar panel, and a $12 \mathrm{~V}$ deep cycle battery (figure 3). Due to the differences in water depth of the monitoring locations (figure 4), two different strategies were employed for water sampling. For the four main channel sites (sites 1,2,5, and 7), the flowmeters were programmed to enable the sampling when the water level reached $0.9 \mathrm{~m}(3 \mathrm{ft})$, and for the three tributary sites (sites 3, 4, and 6), the flowmeters were programmed to enable sampling when the water level reached 0.3 $\mathrm{m}(1 \mathrm{ft})$. This also required us to configure field instruments differently for water sampling. For the deeper sites (sites 1, 2, 5, and 7), a floating suction strainer system was constructed. The floating suction strainer was housed within a $3.6 \mathrm{~m}(12 \mathrm{ft})$ perforated 20.3 $\mathrm{cm}$ (8 in) PVC pipe. The suction strainer was attached to a $0.95 \mathrm{~cm}$ (0.375 in) vinyl tubing, which ran through two $1.9 \mathrm{~cm}$ (0.75 in) PVC pipes from the suction strainer to the ISCO sampler. The first section of the 1.9 $\mathrm{cm}$ PVC pipe ended after the end-cap of the outer $20.3 \mathrm{~cm}$ PVC pipe to allow slack in the vinyl tubing in the occasions of water level rise. The second section of the $1.9 \mathrm{~cm}$ PVC pipe that started from the anchor post ended right at the sampler. The flotation was achieved by sliding the $1.9 \mathrm{~cm}$ PVC pipe, housing the $0.95 \mathrm{~cm}$ vinyl tube attached to the suction strainer, through the two pieces of $20.3 \mathrm{~cm}$ by $19.7 \mathrm{~cm}$ (7.75 in) styrofoams. A hose clamp was placed on the $1.9 \mathrm{~cm}$ PVC pipe right above the $20.3 \mathrm{~cm}$ PVC pipe end-

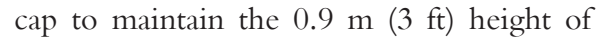
the suction strainer from the bottom of the stream. To determine the rise on water level, a separate $1.9 \mathrm{~cm}$ PVC pipe was run from the flowmeter down the anchor post and ended $15.2 \mathrm{~cm}$ (6 in) above the bottom of the stream. This PVC pipe housed $0.63 \mathrm{~cm}$ (0.25 in) vinyl tubing bubbler line. Water sampling started after the water level reached $0.9 \mathrm{~m}$. Sampling was done $20 \mathrm{~cm}$ (7.9 in) below the water surface. For the shallow sites (sites 3, 4, and 6), a stationary suction strainer system was constructed. This was accomplished simply by bolting two pieces of metal together perpendicularly with the suction strainer attached to the lateral piece and the vertical piece hammered into the stream bed. The suction strainer was placed $15.2 \mathrm{~cm}$ above the stream bed. A $1.9 \mathrm{~cm}$ PVC pipe, which housed $0.63 \mathrm{~cm}$ vinyl tubing bubbler line, was run from the flowmeter to the vertical post and ended about $10.16 \mathrm{~cm}$ (4 in) above the bottom of the stream. For all sampling sites, the samplers were programmed to take an initial $1 \mathrm{~L}(33.81 \mathrm{oz})$ sample when first enabled by the flowmeter, then $1 \mathrm{~L}$ sample was taken every hour thereafter and deposited into the same bottle for a composite sample. To avoid contamination of water samples, the samplers were programmed to run two rinse cycles through the suction lines before sampling. The samplers were programmed to capture a total volume of $10 \mathrm{~L}(338.1 \mathrm{oz})$ per rain event. 
Figure 1

Coulee Baton watershed, Louisiana, and the seven water quality monitoring sites in this study.

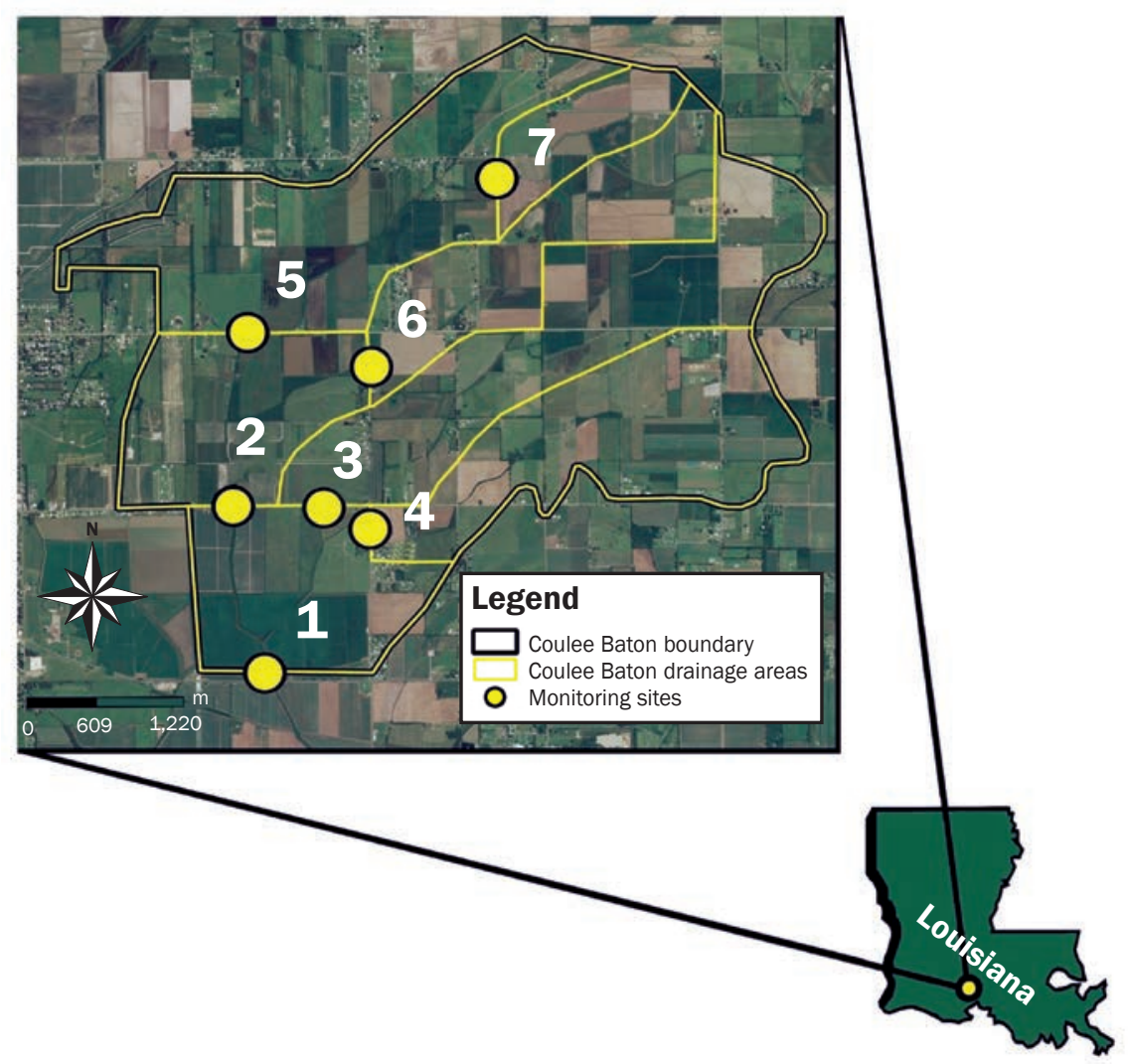

\section{Figure 2}

Histogram showing average monthly rainfall for three years, January of 2009 to December of 2011, at the Coulee Baton watershed nearby Kaplan weather station, Louisiana. The line indicates the average monthly rainfall for the duration of January of 1980 to December of 2008 at the Coulee Baton nearby Abbeville weather station, Louisiana. Precipitation data for 2009 to 2011 at the Abbeville station was incomplete.

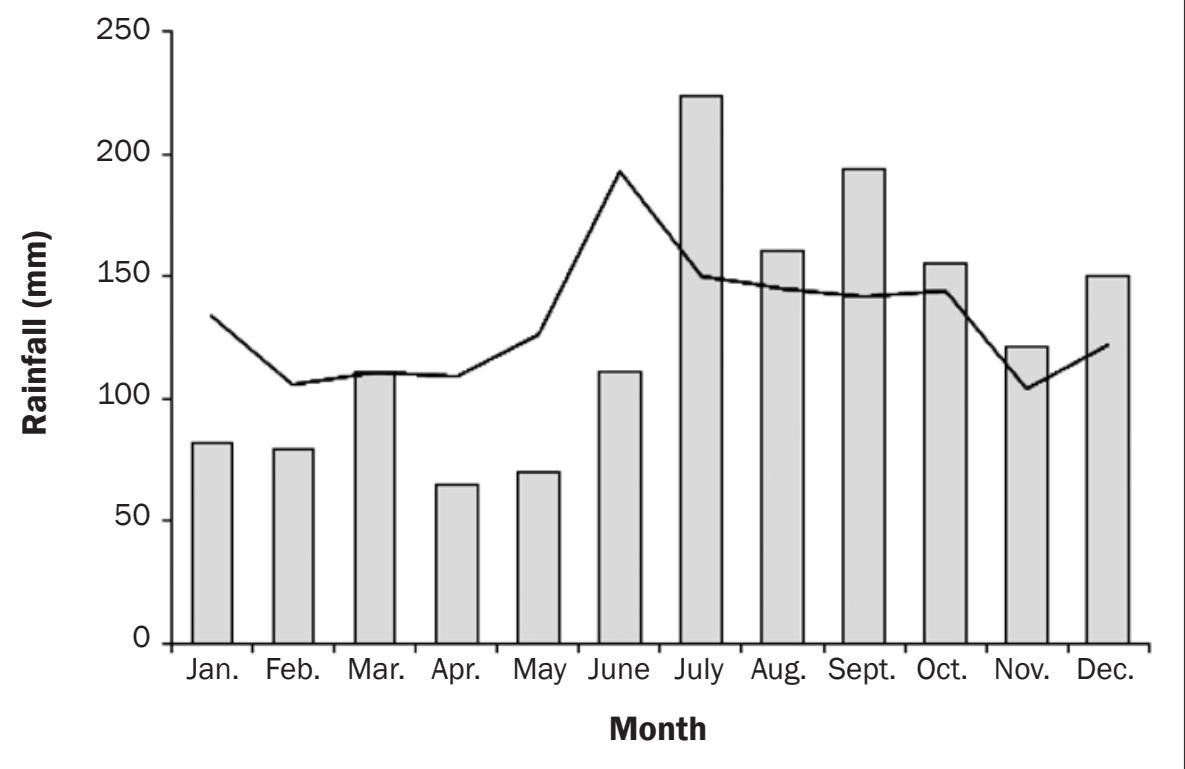

Water sampling began on September 24, 2009, and ended on August 9, 2011. Land use maps were developed from the USDA National Agricultural Statistics Service database (USDA NASS 2014) for the years of 2009, 2010, and 2011 for Coulee Baton watershed showing rice, sugarcane, aquaculture, and pasture as the major land use types during these three years in the drainage areas of each monitoring location (figure 5). Water samples were collected for 66 rain events during the sampling period. Each sample consisted of $1 \mathrm{~L}$ (33.81 oz) of composite sample for laboratory determinations. In those situations when there was not sufficient water depth for automated sampling, water samples were collected by grab method. In this case, water sampling consisted of lowering a plastic bucket from the bridge and collecting a composite sample at $80 \%$ water depth from the surface of water. In order to avoid cross contamination, the sampling bucket lowered from the bridge was rinsed thoroughly from the first collection of water sample from the site, and then it was lowered again for actual sample collection. The water sample from the bucket was transferred to a bottle by dipping the bottle into the water. The water sample bottles were immediately capped, labeled, and put into the ice chest with ice packs. Water samples were transported to the laboratory immediately after completing the sampling. Water samples were used for the determination of TSS, total dissolved solids (TDS), total solids (TS), five-day biological oxygen demand $\left(\mathrm{BOD}_{5}\right), \mathrm{NO}_{3} / \mathrm{NO}_{2}-\mathrm{N}, \mathrm{TKN}$, SRP, $\mathrm{TP}$, chloride $(\mathrm{Cl})$, fluoride ( $\mathrm{Fl})$, sulfate $\left(\mathrm{SO}_{4}\right)$, and fecal coliform counts in the laboratory using USEPA approved standard methods (Clesceri et al. 1998).

Field measurements during each sampling event involved the recording of surface water temperature $\left({ }^{\circ} \mathrm{C}\right)$, conductivity $\left(\mathrm{mS} \mathrm{cm} \mathrm{cm}^{-1}\right)$, $\mathrm{pH}$, turbidity (NTU), and DO $\left(\mathrm{mg} \mathrm{L}^{-1}\right)$ in the field using a multiprobe YSI Sonde (YSI Incorporated,Yellow Springs, Ohio) attached to a handheld data logger (YSI Sonde model 6820 with 650MDS) at each site. Field measurements were taken at three different water depths $(20 \%, 60 \%$, and $80 \%)$ from the marked point at the bridge and were averaged. Before going to the field, the YSI probes were calibrated and the membrane for DO sensor was replaced. The YSI Sonde was cleaned after each measurement and the probes were kept moist. 
Table 1

Total area and the proportion of areas under rice production, sugarcane crop, aquaculture, pasturelands, and others land use types in 2009, 2010, and $\mathbf{2 0 1 1}$ for the seven water quality monitoring sites in Coulee Baton watershed in Louisiana.

\begin{tabular}{|c|c|c|c|c|c|c|c|c|c|c|c|c|c|c|c|c|}
\hline \multirow[b]{2}{*}{ Site } & \multirow{2}{*}{$\begin{array}{l}\text { Total } \\
\text { area } \\
\text { (ha) }\end{array}$} & \multicolumn{3}{|l|}{ Rice } & \multicolumn{3}{|c|}{ Sugarcane } & \multicolumn{3}{|c|}{ Aquaculture } & \multicolumn{3}{|c|}{ Pastureland } & \multicolumn{3}{|c|}{ Others* } \\
\hline & & 2009 & 2010 & 2011 & 009 & 2010 & 2011 & 2009 & 2010 & 2011 & 2009 & 2010 & 2011 & 2009 & 2010 & 2011 \\
\hline 1 & 294.6 & 0.365 & 0.316 & 0.367 & 0.021 & 0.136 & 0.214 & 0.003 & 0.121 & 0.001 & 0.451 & 0.316 & 0.349 & 0.161 & 0.111 & 0.069 \\
\hline 2 & 299.5 & 0.095 & 0.107 & 0.008 & 0.164 & 0.109 & 0.069 & 0.042 & 0.142 & 0.082 & 0.501 & 0.382 & 0.542 & 0.199 & 0.259 & 0.299 \\
\hline 3 & 493.3 & 0.142 & 0.089 & 0.148 & 0.266 & 0.313 & 0.141 & 0.062 & 0.103 & 0.107 & 0.397 & 0.372 & 0.401 & 0.134 & 0.124 & 0.203 \\
\hline 4 & 419.7 & 0.025 & 0.078 & 0.001 & 0.360 & 0.272 & 0.216 & 0.008 & 0.002 & 0.002 & 0.438 & 0.554 & 0.597 & 0.170 & 0.094 & 0.185 \\
\hline 5 & 548.8 & 0.243 & 0.192 & 0.105 & 0.141 & 0.118 & 0.074 & 55 & 0.133 & 0.138 & 0.423 & 0.395 & 0.503 & 0.138 & 0.162 & 0.180 \\
\hline 6 & 308.8 & 0.231 & 0.176 & 0.131 & 0.228 & 0.166 & 0.100 & 0.067 & 0.178 & 0.211 & 0.270 & 0.270 & 0.253 & 0.204 & 0.210 & 0.305 \\
\hline 7 & 128.3 & 0.416 & 0.464 & 0.202 & 0.110 & 0.082 & 0.028 & 0.110 & 0.060 & 0.391 & 0.287 & 0.319 & 0.230 & 0.076 & 0.076 & 0.148 \\
\hline
\end{tabular}

*Others include developed, fallow/idle cropland, open water, shrubland, soybeans (Glycine max), winter wheat (Triticum aestivum), woody wetland, and sorghum (Sorghum bicolor) areas.

\section{Figure 3}

Field instrumentation for water quality sampling. (a) A box housing ISCO sampler, flowmeter and a battery; (b) rain gauge and a solar panel connected to the battery; (c) a perforated PVC pipe housing a suction strainer with suction hose floated with the help of a styrofoam; and (d) a suction strainer, sitting on a metal piece at $15.24 \mathrm{~cm}$ off the bottom of stream, connected to ISCO sampler through a conduit PVC pipe, and a bubble line for a bubbler flowmeter at the Coulee Baton watershed, Louisiana.

(a)

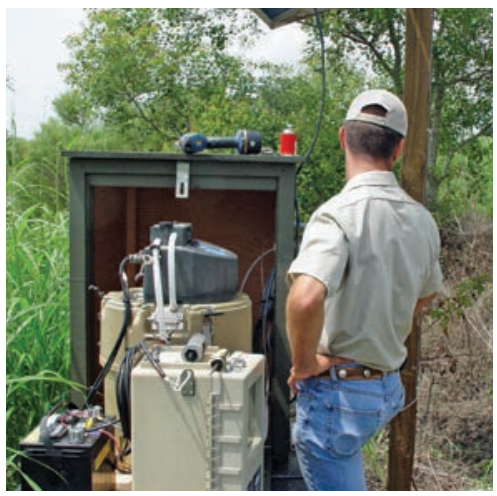

(c)

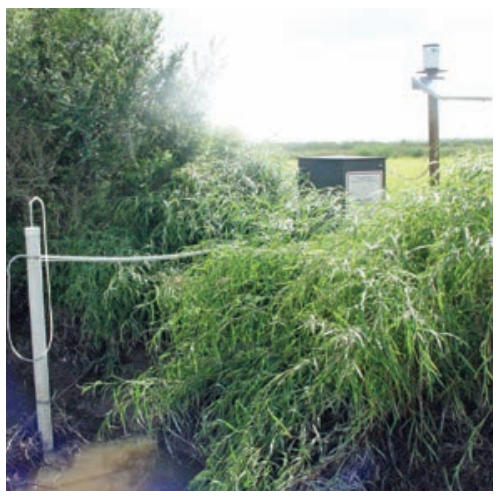

(b)

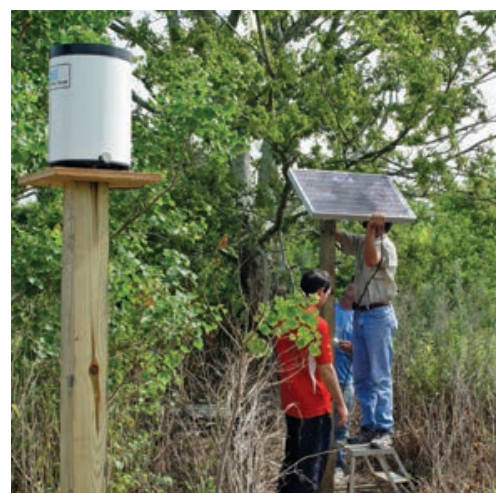

(d)

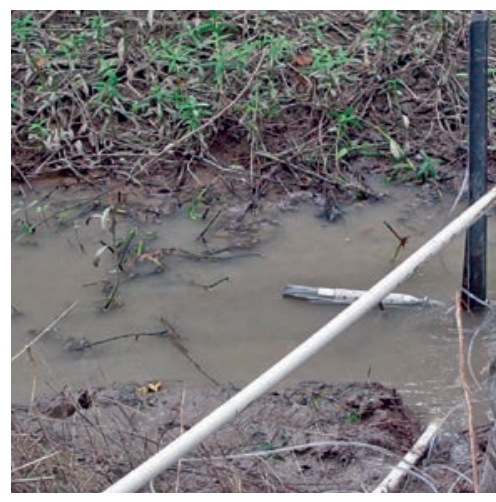

Implementation of Best Management Practices. In collaboration with theVSWCD, the USDA NRCS developed a plan for voluntary application of various conservation measures and BMPs on the land by land- ers in 2006 to 2007. The installation of BMPs in the watershed started in May of 2007 and continued until December of 2010. During this time, the BMPs installed by the drainage areas included one heavy use protection (pad under water trough) and $726.9 \mathrm{~m}(2,385 \mathrm{ft})$ of fence covering $44.9 \mathrm{ha}(111 \mathrm{ac})$ for site 1 , and $975.4 \mathrm{~m}(3,200 \mathrm{ft})$ of pipeline, one well, and one pipe drop structure for site 3 . Likewise, the 20.2 ha $(50 \mathrm{ac})$ of land under BMP implementation in site 5 drainage areas included 13.7 ha $(34 \mathrm{ac})$ of irrigation land leveling and one grade stabilization structure, and site 6 had 7.3 ha $(18 \mathrm{ac})$ of land under irrigation land leveling. Additionally, in between November of 2008 and September of 2010, through the cost-share reimbursement program, the VSWCD together with the Acadiana Resource Conservation and Development Council and the Louisiana Department of Environmental Quality replaced or repaired 80 rural sewer systems with gravel line system out of 230 homes in the Coulee Baton watershed. Most of these installations were carried out during April of 2010 to September of 2010, when the cost share was changed from original $60 \%$ to $90 \%$. These 80 repaired rural systems were approximately distributed as 15 in site 1,1 in site 2 , 17 in site 3,15 in site 4, 8 in site 5,23 in site 6 , and 1 in site 7 drainage areas.

Data Analyses. Statistical analyses, such as simple statistics, percentiles, range, means, medians, students' t-test, and the Wilcoxon/ Kruskal-Wallis tests (rank sums) were done in JMP (SAS Institute Inc. 2009). In order to assess the effects of BMPs on surface water quality, the water quality data set was divided as ongoing BMPs (January 1, 2010, to August 9,2010 ) and post-BMPs (January 1, 2011, to August 9,2011 ) for the four exclusive sites (sites 3, 4, 6, and 7), a monitoring site that 


\section{Figure 4}

Mean water depth of the seven water quality monitoring sites in Coulee Baton watershed, Louisiana.

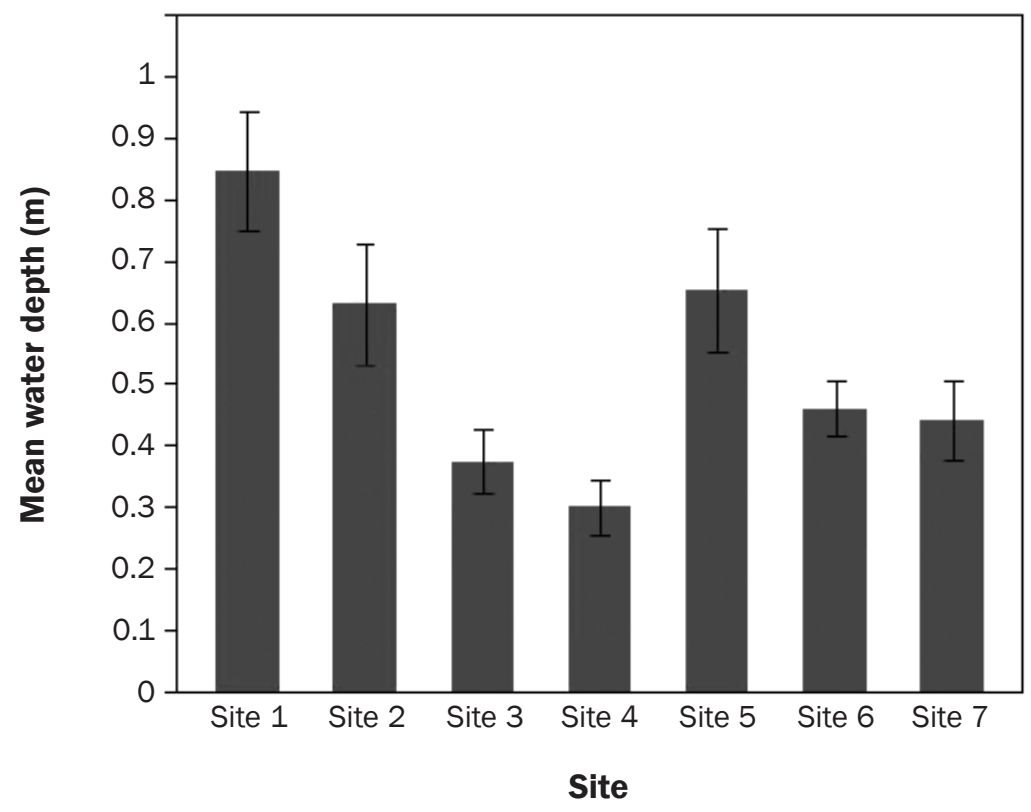

did not receive water from another monitoring site, and two-sample students' t-test with independent sample. Additionally, graphs showing variation in concentrations of water quality parameters that showed significant difference in mean comparison across the four exclusive sites were developed. Land use effects on surface water quality was assessed by comparing means for the four exclusive sites with Tukey-Kramer HSD test at 0.05 probability level.

\section{Results and Discussion}

Spatial Variability of Surface Water Quality. A large spatial variability exists on the surface water quality of the Coulee Baton watershed. The Wilcoxon/Kruskal-Wallis tests (rank sums) showed significant differences among the seven water quality monitoring sites for conductivity $(p \leq 0.05), \mathrm{pH}(p \leq 0.01)$, turbidity $(p \leq 0.001)$, DO $(p \leq 0.001)$, TSS $(p \leq$ $0.05)$, TDS $(p \leq 0.001), \mathrm{TS}(p \leq 0.001), \mathrm{NO}_{3} /$ $\mathrm{NO}_{2}-\mathrm{N}(p \leq 0.05), \mathrm{BOD}_{5}(p \leq 0.05), \mathrm{Cl}(p$ $\leq 0.001)$, TP $(p \leq 0.01)$, and TKN $(p \leq 0.05)$. Site 1 , the outlet site, showed the highest median concentrations for TSS $\left(103 \mathrm{mg} \mathrm{L}^{-1}\right)$, TDS (252.5 $\left.\mathrm{mg} \mathrm{L}^{-1}\right)$, TS (402.5 $\left.\mathrm{mg} \mathrm{L}^{-1}\right)$, and turbidity (223.5 NTU); while a tributary site, site 6 , showed the highest median concentrations for TKN $\left(1.29 \mathrm{mg} \mathrm{L}^{-1}\right)$ and $\mathrm{NO}_{3}$ / $\mathrm{NO}_{2}-\mathrm{N}\left(1.28 \mathrm{mg} \mathrm{L}^{-1}\right)$; and another tributary site, site 4 , showed the highest median concentration for TP $\left(0.48 \mathrm{mg} \mathrm{L}^{-1}\right)$ (figure $6)$. An overall comparison between the tributary sites (sites 3, 4, and 6) and the main channel sites (sites 1,2,5, and 7) showed, on average, significantly higher values for TDS $(p \leq 0.01)$ and turbidity $(p \leq 0.01)$ for the main channel sites and a significantly higher value for TKN $(p \leq 0.01)$ for the tributary sites (table 2). On average, the main channel sites had $41 \%$ higher concentrations for TDS and $47.5 \%$ higher turbidity value compared to the tributary sites, whereas the tributary site, on average, had $24.2 \%$ higher concentrations for TKN compared to the main channel sites. These results suggest that there was a higher sediment transport capacity of the main channel due to an increased flow condition following a rain event resulting in a cumulative effect in sediment pollution, whereas the tributaries still had low flow condition, possibly resulting in sediment deposits. Higher concentrations of $\mathrm{N}$ in the tributary sites suggests a dilution effect of $\mathrm{N}$ pollution in the watershed. Stream bank erosion also contributes to sediment load in a low-gradient agricultural watershed (Neal and Anders 2015).

At site 1, the outlet site of the watershed, highly elevated TDS values were observed on March 1, 2011 (3,425 mg L $\left.{ }^{-1}\right)$, on March

\section{Figure 5}

Land use types of the seven water quality monitoring drainage areas in (a) 2009, (b) 2010, and (c) 2011 in the Coulee Baton watershed in Louisiana.

(a)

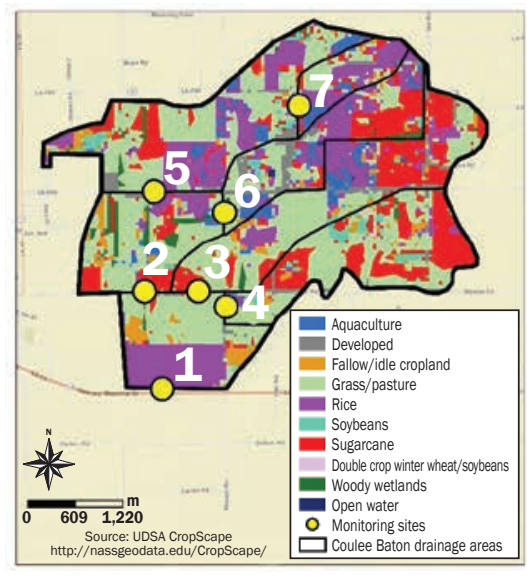

(b)

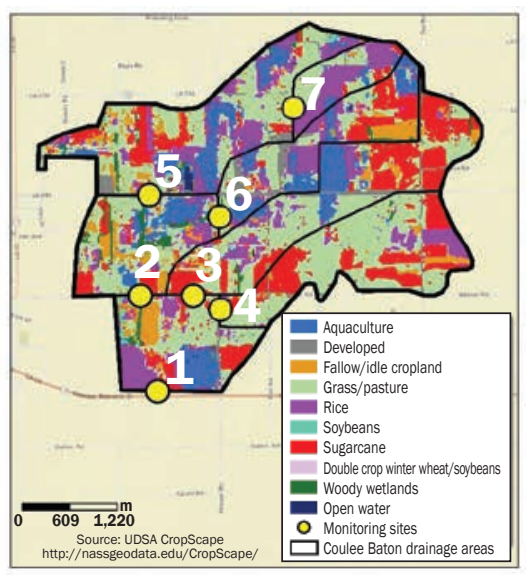

(c)

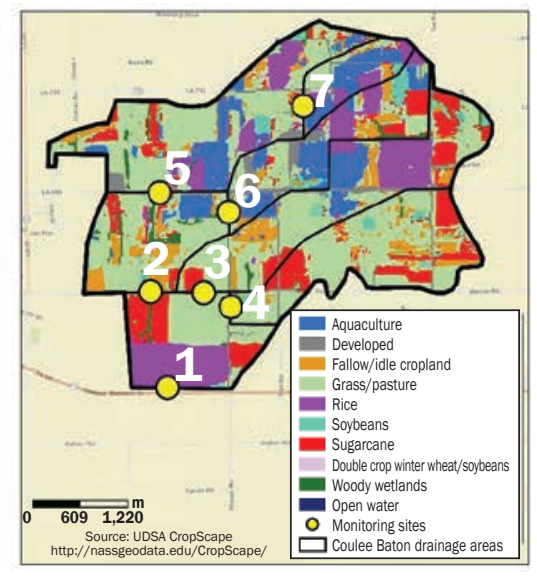




\section{Figure 6}

Median, 25th percentile, and 75th percentile values of (a) dissolved oxygen (DO), (b) surface water temperature, (c) turbidity, (d) conductivity, (e) $\mathrm{pH}$, (f) total suspended solids (TSS), (g) total dissolved solids (TDS), (h) total solids (TS), (i) nitrate/nitrite- $\left.\mathrm{N}_{(\mathrm{NO}} / \mathrm{NO}_{2}-\mathrm{N}\right)$, (j) total Kjeldahl nitrogen (TKN), ( $k$ ) soluble reactive phosphate (SRP), (l) total phosphorus (TP), (m) five-day biological oxygen demand (BOD) (p) sulfate, and (q) fecal coliform counts for the seven water quality monitoring sites of the Coulee Baton watershed, Louisiana (September of 2009 to August of 2011). The whiskers represent the 3 rd quartile $+1.5 \times$ interquartile range and 1 st quartile $-1.5 \times$ interquartile range. Sample size (n) ranged from 62 to 66 for these parameters.

(a)

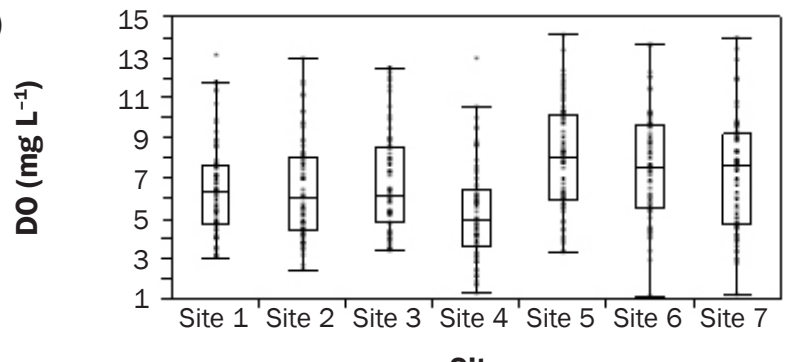

Site

(c)

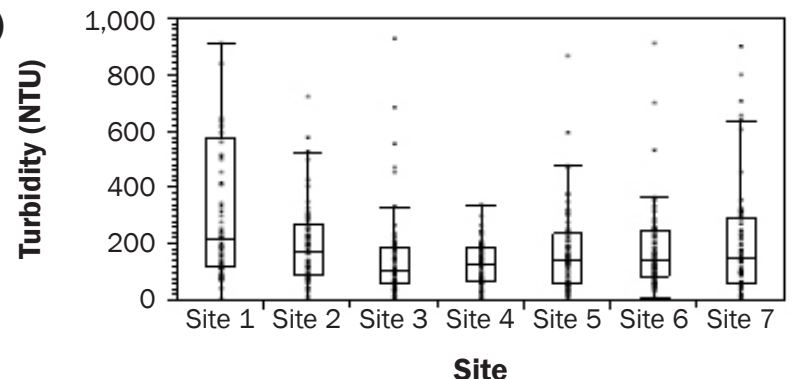

(e)

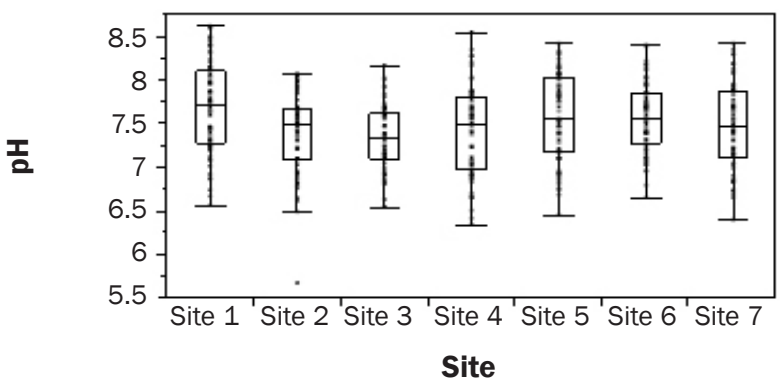

(g)

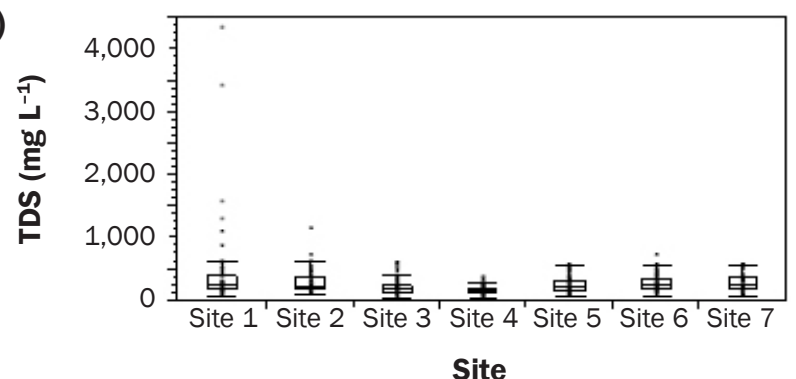

(i)

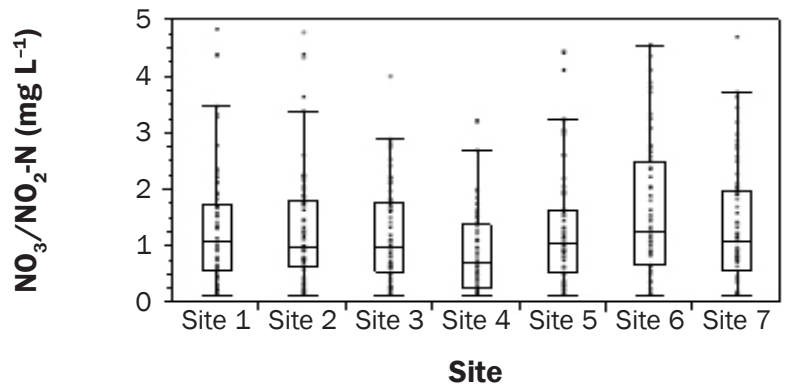

(b)

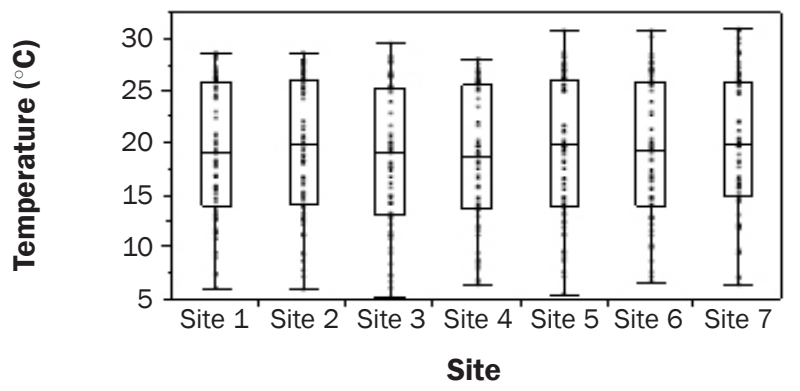

(d)

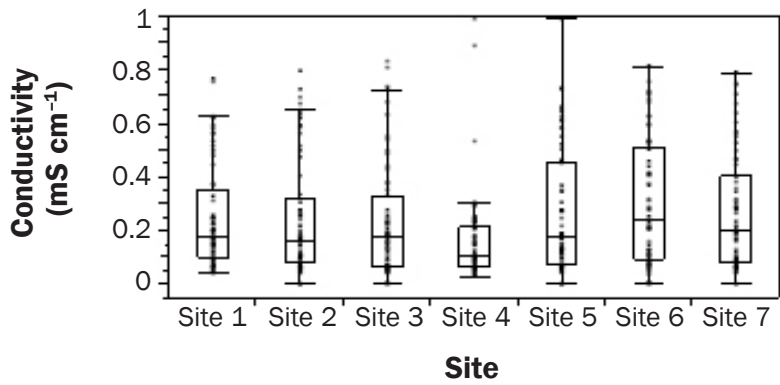

(f)

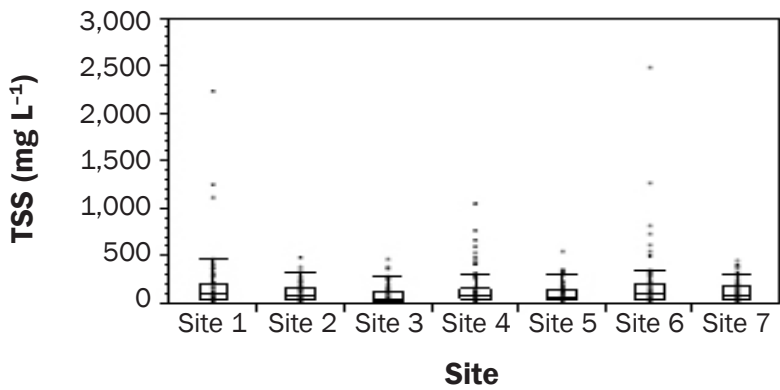

(h)

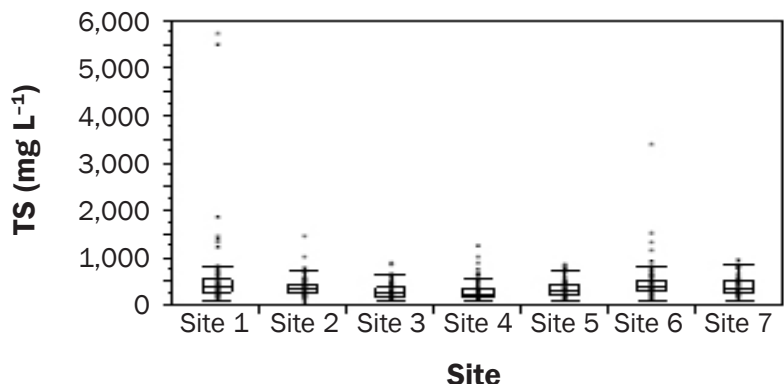

(j)

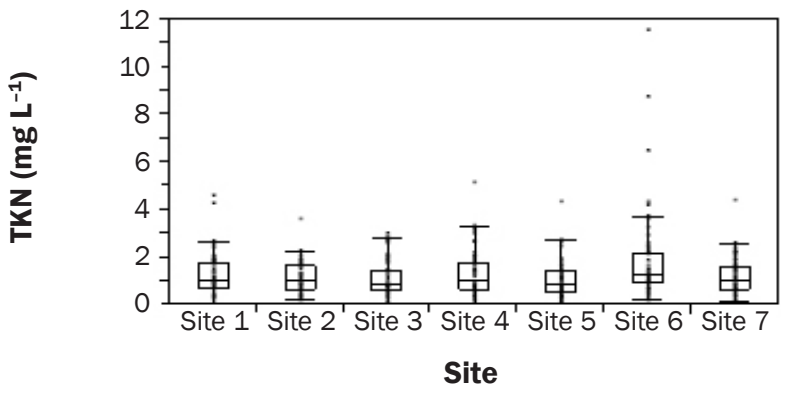




\section{Figure 6 Continued}

(k)

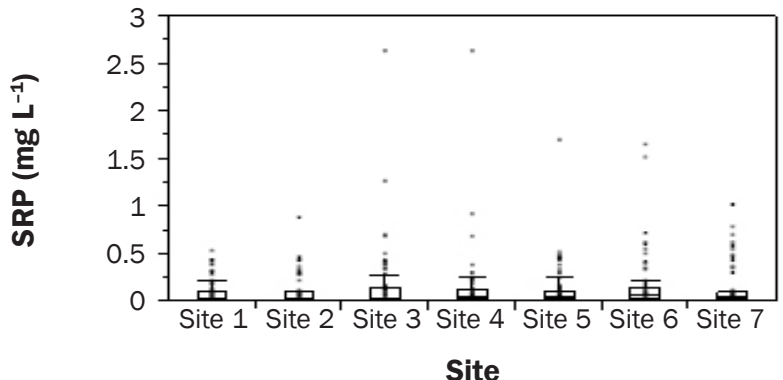

(m)

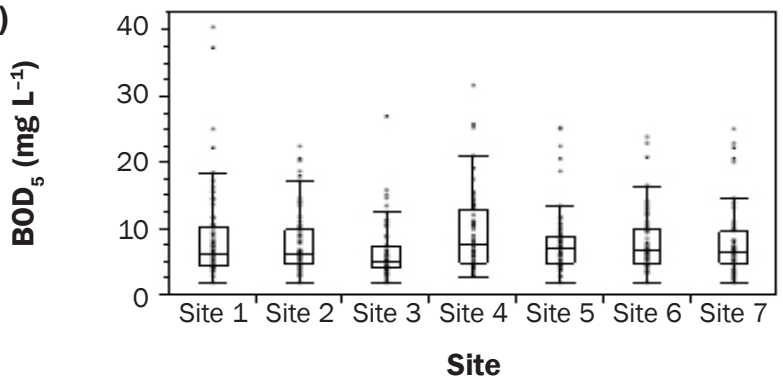

(o)

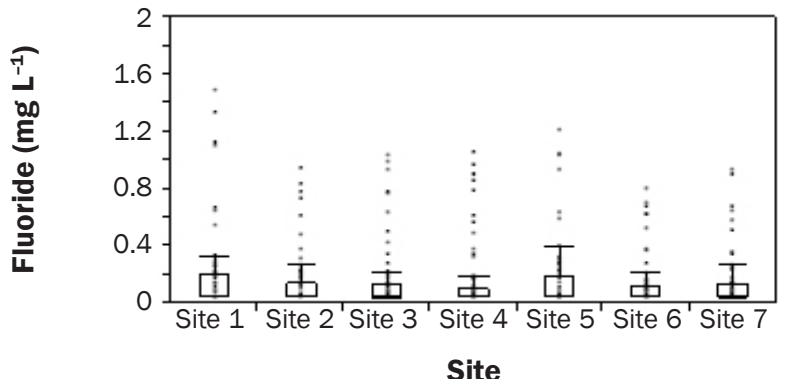

(q)

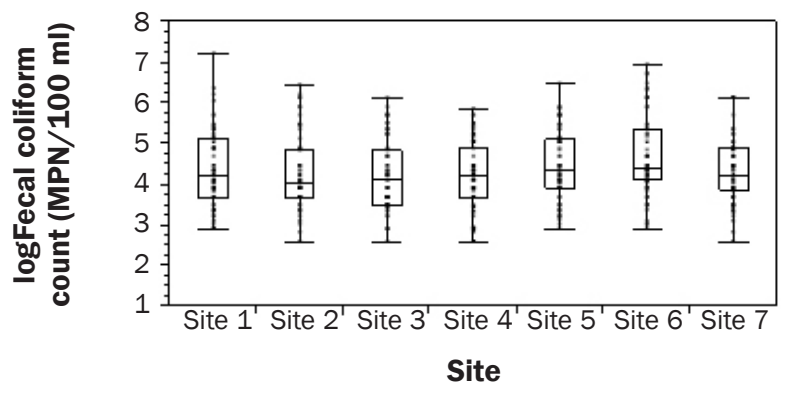

(l)

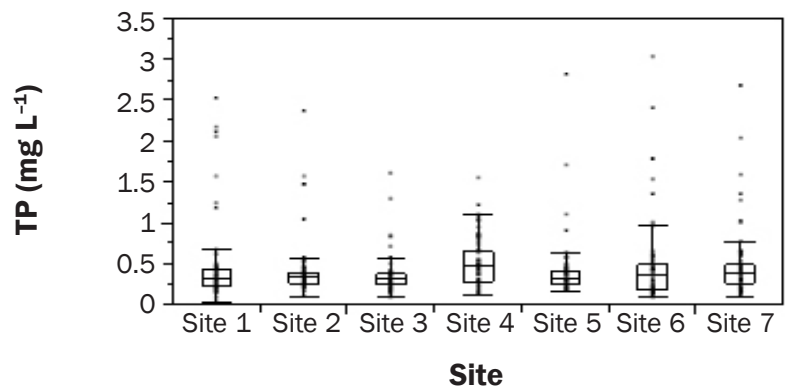

(n)

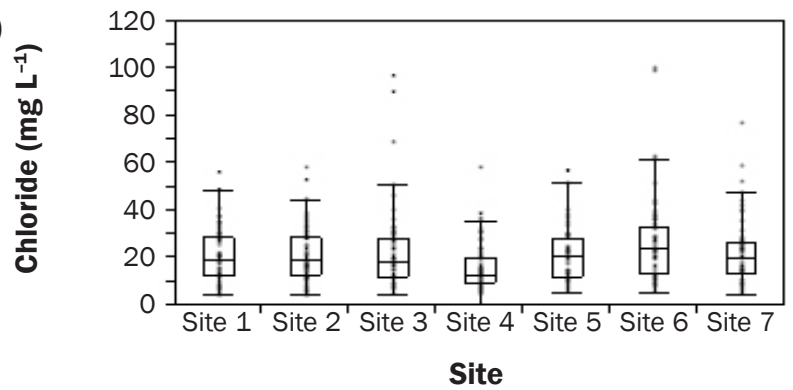

(p)

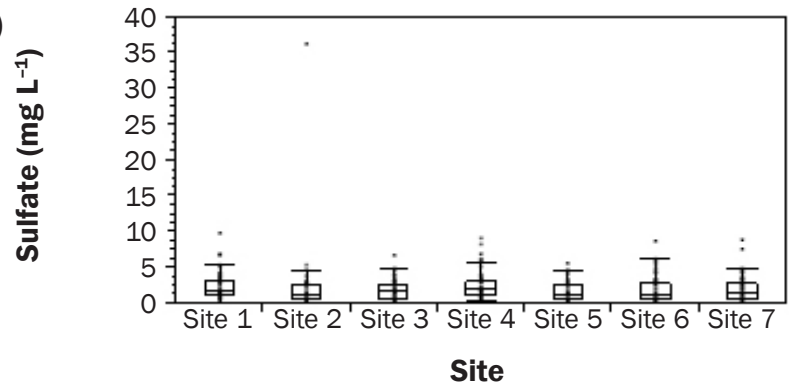

22, 2011 (1,088 $\left.\mathrm{mg} \mathrm{L}^{-1}\right)$, on March 29, 2011 $\left(4,356 \mathrm{mg} \mathrm{L}^{-1}\right)$, on April 5, 2011 (1,573 mg $\left.\mathrm{L}^{-1}\right)$, and on April 19, 2011 (1,305 $\left.\mathrm{mg} \mathrm{L}^{-1}\right)$. These results indicate that the TDS has a cumulative effect and the dissolved substances leave the watershed very quickly following a rain event. The dissolved substances in the surface water are reactive and will potentially cause algal growth, aquatic selenium pollution, and disturbances in ecological balance (Lemly 2004; Thomas 2009). Therefore, it is important to identify the sources of these TDS fluxes and pay attention to control these fluxes in order to improve surface water quality downstream. Sources of TDS in an agricultural watershed include inorganic chemicals, such as fertilizers and pesticides applied to agricultural lands, agricultural drainage water, wastewater disposals, surface runoff from built-up areas such as roads and parking lots, residential areas including flower-beds and lawns, dissolved organic carbon (C), and other natural sources. In southwestern Louisiana, rice is planted from late February to early May either as water-seeded, which is sowing of dry or soaked seeds by air into a flooded field, or dry-planted, which involves drill- ing or broadcasting seeds into a dry seedbed (LSU AgCenter 2000). Flood water from wet-planted rice fields is drained within 24 hours in order to protect germinating seeds from dying due to submergence (Huner et al. 2002). Water management during the growing season in Louisiana rice fields varies according to rice planting methods (waterseeded versus dry-seeded systems) and associated flooding systems (LSU AgCenter 2014). In delayed-flood systems, waterseeded rice fields are drained for three to four weeks before permanent flooding, while in pinpoint flood systems, water-seeded rice 


\section{Table 2}

Average surface water temperature, conductivity, $\mathrm{pH}$, turbidity, dissolved oxygen (DO), total suspended solids (TSS), total dissolved solids (TDS), total solids (TS), nitrate/nitrite- $\mathrm{N}_{\left(\mathrm{NO}_{3} /\right.}$ $\left.\mathrm{NO}_{2}-\mathrm{N}\right)$, five-day biological oxygen demand $\left(\mathrm{BOD}_{5}\right)$, chloride, fluoride, sulfate $\left(\mathrm{SO}_{4}\right)$, soluble reactive phosphate (SRP), total phosphorus (TP), total Kjeldahl nitrogen (TKN), and fecal coliform counts for the main channel sites (sites 1, 2, 5, and 7) as a whole and the tributary sites (sites 3, 4, and 6) as a whole in the Coulee Baton watershed, in southwestern Louisiana (September of 2009 to August of 2011).

\begin{tabular}{|c|c|c|c|c|}
\hline \multirow[b]{2}{*}{ Parameter } & \multicolumn{2}{|c|}{ Main channel } & \multicolumn{2}{|c|}{ Tributary } \\
\hline & $n$ & Mean & $n$ & Mean \\
\hline Temperature $\left({ }^{\circ} \mathrm{C}\right)$ & 260 & $19.52( \pm 0.41) \mathrm{ns}$ & 189 & $18.77( \pm 0.47) \mathrm{ns}$ \\
\hline Conductivity ( $\left.\mathrm{mS} \mathrm{cm}^{-1}\right)$ & 260 & $0.256( \pm 0.013) \mathrm{ns}$ & 189 & $0.234( \pm 0.015) \mathrm{ns}$ \\
\hline $\mathrm{pH}$ & 260 & $7.54( \pm 0.03) *$ & 184 & $7.45( \pm 0.03)^{*}$ \\
\hline Turbidity (NTU) & 260 & $281.51( \pm 19.61) * *$ & 189 & $190.81( \pm 23.00) * *$ \\
\hline $\mathrm{DO}\left(\mathrm{mg} \mathrm{L}^{-1}\right)$ & 259 & $7.09( \pm 0.16) \mathrm{ns}$ & 188 & $6.59( \pm 0.19) n s$ \\
\hline TSS (mg L-1) & 264 & $143.23( \pm 13.39) n s$ & 190 & $160.58( \pm 15.79) \mathrm{ns}$ \\
\hline TDS (mg L-1) & 264 & $310.03( \pm 17.84) * *$ & 190 & $220.87( \pm 21.03) * *$ \\
\hline TS $\left(\mathrm{mg} \mathrm{L}^{-1}\right)$ & 264 & $451.85( \pm 27.05) \mathrm{ns}$ & 190 & $384.48( \pm 31.89) n s$ \\
\hline $\mathrm{NO}_{3} / \mathrm{NO}_{2}-\mathrm{N}\left(\mathrm{mg} \mathrm{L}^{-1}\right)$ & 264 & $1.317( \pm 0.062) \mathrm{ns}$ & 191 & $1.228( \pm 0.073) \mathrm{ns}$ \\
\hline $\mathrm{BOD}_{5}\left(\mathrm{mg} \mathrm{L}^{-1}\right)$ & 264 & $8.19( \pm 0.033) \mathrm{ns}$ & 191 & $8.07( \pm 0.39) n s$ \\
\hline Chloride (mg L-1) & 264 & $21.43( \pm 0.88) \mathrm{ns}$ & 191 & $22.04( \pm 1.03) \mathrm{ns}$ \\
\hline Fluoride $\left(\mathrm{mg} \mathrm{L}^{-1}\right)$ & 264 & $0.159( \pm 0.014) n s$ & 191 & $0.150( \pm 0.017) \mathrm{ns}$ \\
\hline $\mathrm{SO}_{4}\left(\mathrm{mg} \mathrm{L}^{-1}\right)$ & 264 & $2.055( \pm 0.139) \mathrm{ns}$ & 191 & $2.067( \pm 0.167) \mathrm{ns}$ \\
\hline $\mathrm{SRP}\left(\mathrm{mg} \mathrm{L}^{-1}\right)$ & 264 & $0.126( \pm 0.016) \mathrm{ns}$ & 191 & $0.169( \pm 0.019) \mathrm{ns}$ \\
\hline $\mathrm{TP}\left(\mathrm{mg} \mathrm{L}^{-1}\right)$ & 264 & $0.458( \pm 0.024) \mathrm{ns}$ & 191 & $0.462( \pm 0.029) \mathrm{ns}$ \\
\hline TKN (mg L-1) & 264 & $1.152( \pm 0.063)^{* *}$ & 191 & $1.431( \pm 0.074) * *$ \\
\hline $\begin{array}{l}\text { Fecal coliform } \\
\text { (MPN per } 100 \mathrm{~mL} \text { ) }\end{array}$ & 259 & $219,154(64,234) n s$ & 188 & $248,340( \pm 75,394) n s$ \\
\hline
\end{tabular}

$* p<0.05 * * p<0.01 * * * p<0.001$

Note: Means followed by ns are not significantly different at 0.05 probability level by the two sample student's t-test with independent sample. MPN = most probable number. Numbers in parentheses are \pm standard error of mean. ns $=$ not significant.

fields are drained for three to five days before they are permanently flooded. Permanent flooding of a dry-seeded rice field occurs when the rice plants reach four to five leaf stage. After permanent flooding, with some exceptions of midseason drainage for the control of rice disease, rice fields are drained about two to three weeks before harvesting. With regard to crawfish production, new crawfish ponds are prepared in spring, stocked with crawfish late spring, and ponds are drained between early June and early July and are flooded during the fall-winter-spring period (Huner et al. 2002). Crawfish is harvested generally in November/December in old ponds and February/March in new ponds, and harvesting continues as long as the harvest is economically viable until the ponds are drained in the summer. Farmers drain crawfish ponds in the month of March or April if they anticipate low crawfish harvest in that year and decide to plant rice in their fields. In case of sugarcane, which is generally grown as a four-year cycle crop, the standard management practice for a new planting includes plowing and leveling the field in May, disking in June, and row making and planting sugarcane in August/September. Sugarcane crop is cultivated and fertilized with $\mathrm{N}, \mathrm{P}$, and potassium (K) in March/April and is harvested in late fall. The standard pasture management practice in southwestern Louisiana include conventional grazing and producing hay from excess forage in summer. Some farmers apply N, P, and K fertilizers to their pasturelands occasionally in the months of March and November. During the winter months when grasses die in pasturelands, cattle are concentrated in certain areas and are fed with hay, which generates stockpile of manures in the feeding areas. Thus, these fluxes of TDS in this study apparently relate to the application of fertilizers and other chemicals in agricultural lands, drainage water from rice fields and crawfish ponds, surface runoff from pasturelands and other areas in the watershed, and possibly septic system failures and wastewater disposals.
Monthly Variability of Surface Water Quality. Coinciding with the seasonal agricultural activities in the watershed, results from the monthly analysis of the surface water quality data showed increased concentrations of sediments and nutrients in early spring, which remained elevated throughout the summer and the fall (figure 7). The months of March, April, and June, on average, showed higher concentrations of sediments and $\mathrm{N}$ in the watershed. While the month of March showed the highest monthly average concentrations for TS $\left(702.61 \mathrm{mg} \mathrm{L}^{-1}\right)$ and TDS (501.30 $\mathrm{mg} \mathrm{L}^{-1}$ ), the month of April showed the highest average concentrations

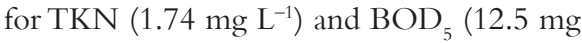
$\left.\mathrm{L}^{-1}\right)$. The month of April, on average, also showed the highest fecal coliform counts $(850,385$ most probable number [MPN] per $100 \mathrm{~mL}$ ). The month of June showed the highest monthly average concentration for $\mathrm{NO}_{3} / \mathrm{NO}_{2}-\mathrm{N}\left(1.95 \mathrm{mg} \mathrm{L}^{-1}\right)$. Several reasons for these elevated monthly average concentrations of the Coulee Baton surface water include (1) higher amount of rainfall and subsequent runoff from the landscape in the month of March (figure 2); (2) agricultural activities, such as drainage of crawfish ponds or rice fields during these months; (3) feeding hay to the cattle during winter months, resulting in stockpile of manure in one area, which may get washed into the waterway through surface runoff in the spring; (4) arrival of migratory birds in the landscape; and (5) the application of $\mathrm{N}$ fertilizers in agricultural lands from late March to June. Similar to this seasonality of the fluxes of nutrients and sediments in the Coulee Baton watershed, Southwick et al. (2002) reported higher concentrations of atrazine for the months of February, May to early June, late July and August, and October, with the highest concentration generally occurring in May to June, in four waterbodies in southwestern Louisiana. Higher concentrations of atrazine in the waterbodies coincided with its applications to various agricultural crops in spring, after planting sugarcane in late summer, and after harvesting sugarcane crop in late fall.

The month of August, when agricultural activities such as drainage of rice fields and crawfish ponds and land preparation for new sugarcane crops occur, showed higher monthly average concentrations for TSS (220 $\mathrm{mg} \mathrm{L}^{-1}$ ) (figure 7). Similarly, the month of September showed the highest monthly 
average concentrations for SRP $\left(0.91 \mathrm{mg} \mathrm{L}^{-1}\right)$ and TP $\left(1.81 \mathrm{mg} \mathrm{L}^{-1}\right)$, reflecting the application of $\mathrm{P}$ fertilizers during late summer or early fall, especially in newly planted sugarcane fields or in newly prepared rice fields for spring planting. Increased concentrations of $\mathrm{P}$ in runoff from croplands exacerbates the algal blooms in surface waterbodies (Andraski and Bundy 2003). In this study, monthly average concentrations of $\mathrm{Cl}$ and $\mathrm{Fl}$ were high for the month of September, and the monthly average concentration of $\mathrm{SO}_{4}$ was high for the month of January. However, the fluxes of $\mathrm{Cl}$ and $\mathrm{SO}_{4}$ were within the threshold limits set by LDEQ (LDEQ 2014). Louisiana does not have Fl standard, but if we compare $\mathrm{Fl}$ concentrations in Coulee Baton watershed with the USEPA standard for Kansas state $\left(1 \mathrm{mg} \mathrm{L}^{-1}\right.$ for irrigation and $2 \mathrm{mg} \mathrm{L}^{-1}$ for livestock and domestic water supply) (USEPA 2014), we find Fl concentrations within the limit in this watershed.

Impacts of Best Management Practices on Surface Water Quality. Results from the comparison of ongoing BMPs and the post-BMPs for the four exclusive sites (sites $3,4,6$, and 7) showed significantly lower post-BMPs values forTSS $(p \leq 0.001), \mathrm{NO}_{3} /$ $\mathrm{NO}_{2}-\mathrm{N}(p \leq 0.01)$, SRP $(p \leq 0.001), \mathrm{BOD}_{5}$ $(p \leq 0.001)$, and $\mathrm{SO}_{4}(p \leq 0.001)$ (table 3). As compared to the ongoing BMPs, the postBMPs TSS, $\mathrm{NO}_{3} / \mathrm{NO}_{2}-\mathrm{N}$, SRP, BOD , and $\mathrm{SO}_{4}$ concentrations, on average, were lower by $56.2 \%, 23.1 \%, 82.5 \%, 27.4 \%$, and $47.1 \%$, respectively. On the other hand, as compared to the ongoing BMPs, the post-BMPs TDS, conductivity, and TKN values, on average, were significantly higher by $42.1 \%, 112.2 \%$, and $31.5 \%$, respectively. In general, the levels of BMPs implemented in these four sites included site $6>$ site $3>$ site $4>$ site 7 .

Coinciding with the level of BMPs implementation, a good improvement on post-BMPs surface water quality was observed in the watershed (figure 8). Site 6 showed general improvement on TSS, $\mathrm{NO}_{3} /$ $\mathrm{NO}_{2}-\mathrm{N}, \mathrm{SRP}, \mathrm{SO}_{4}, \mathrm{BOD}_{5}$, and TKN; site 3 showed improvement on $\mathrm{SO}_{4}$ and $\mathrm{BOD}_{5}$; site 4 showed improvement on TSS; and site 7 showed some improvement on $\mathrm{BOD}_{5}$ concentrations after the implementation of BMPs. At site 6, elevated concentrations were observed for TSS on October 1, 2009 (2,481 $\left.\mathrm{mg} \mathrm{L}^{-1}\right)$, and on January 21, $2010\left(1,262 \mathrm{mg} \mathrm{L}^{-1}\right)$; for $\mathrm{NO}_{3} / \mathrm{NO}_{2}-\mathrm{N}$ on October 7, 2010 (4.11 $\mathrm{mg} \mathrm{L}^{-1}$ ), October 28, 2010 (4.56 $\mathrm{mg} \mathrm{L}^{-1}$ ), December 9, 2010
(4.37 $\mathrm{mg} \mathrm{L}^{-1}$ ), December 16, 2010 (3.88 mg $\left.\mathrm{L}^{-1}\right)$, and on January 20, $2011\left(3.34 \mathrm{mg} \mathrm{L}^{-1}\right)$; and for SRP on September 28, 2009 (1.53 $\mathrm{mg} \mathrm{L}^{-1}$ ), and on October 1, 2009 (1.64 mg $\left.\mathrm{L}^{-1}\right)$. Similarly, elevated concentrations were observed for $\mathrm{SO}_{4}$ on June 23, $2010(8.74 \mathrm{mg}$ $\left.\mathrm{L}^{-1}\right)$, July 27, 2010 (5.89 $\left.\mathrm{mg} \mathrm{L}^{-1}\right)$, October 21, $2010\left(6.33 \mathrm{mg} \mathrm{L}^{-1}\right)$, and on January 5, 2011 (5.64 $\left.\mathrm{mg} \mathrm{L}^{-1}\right)$; for $\mathrm{BOD}_{5}$ on October 1, 2009 (23.75 $\mathrm{mg} \mathrm{L}^{-1}$ ), June 23, 2010 (23.02 mg $\mathrm{L}^{-1}$ ), and on April 26, 2011 (20.75 $\left.\mathrm{mg} \mathrm{L}^{-1}\right)$; and for TKN on September 28, 2009 (8.72 $\mathrm{mg} \mathrm{L}^{-1}$ ), and on October 1, 2009 (11.51 mg $\left.\mathrm{L}^{-1}\right)$, at site 6 . Elevated concentrations at site 3 were observed for $\mathrm{SO}_{4}$ on March 9, 2010 (4.82 $\mathrm{mg} \mathrm{L}^{-1}$ ), April 20, 2010 (6.74 $\mathrm{mg} \mathrm{L}^{-1}$ ), and on October 14, 2010 (4.64 $\left.\mathrm{mg} \mathrm{L}^{-1}\right)$; and for BOD on November 15, $2010(27.0 \mathrm{mg}$ $\left.\mathrm{L}^{-1}\right)$. Site 4 showed elevated concentration of TSS on December 7, 2009 (1,055 $\left.\mathrm{mg} \mathrm{L}^{-1}\right)$; and site 7 showed elevated concentrations of BOD ${ }_{5}$ on April 20, 2010 (20.14 $\left.\mathrm{mg} \mathrm{L}^{-1}\right)$, July 1, 2010 (24.92 $\mathrm{mg} \mathrm{L}^{-1}$ ), July 6, 2010 (22.86 $\mathrm{mg} \mathrm{L}^{-1}$ ), October 21, 2010 (22.21 $\mathrm{mg} \mathrm{L}^{-1}$ ), and on April 26, 2011 (20.43 mg $\left.\mathrm{L}^{-1}\right)$. These results demonstrate that most of the elevated concentrations for surface water quality parameters in this watershed occurred during ongoing BMPs, and suggest that there was a good improvement on post-BMPs surface water quality, especially through the reduction nonpoint source pollutants' fluxes. However, the effects of BMPs were not realized on all the water quality parameters at the same level. Elevated $\mathrm{BOD}_{5}$ concentrations were observed at site 4 on April 12, 2011 (25.20 $\left.\mathrm{mg} \mathrm{L}^{-1}\right)$, April 19, 2011 (20.91 mg L $\mathrm{m}^{-1}$ ), May 17, 2011 (20.91 $\mathrm{mg} \mathrm{L}^{-1}$ ), May 24, 2011 (31.54 $\left.\mathrm{mg} \mathrm{L}^{-1}\right)$, and May 31, 2011 (25.73 $\mathrm{mg} \mathrm{L}^{-1}$ ). Similarly, elevated postBMPs TDS and conductivity values were observed for the four sites (figure 8).

Above results suggest that conservation measures impact water quality parameters variably in an agricultural watershed. Therefore, a regular water quality monitoring program is necessary for assessing the effectiveness of conservation measures in controlling nonpoint source pollution in an agricultural watershed. In addition, sufficient caution should be taken when interpreting the reduction of concentrations of nonpoint source pollutants due to the effects of conservation measures, as these changes are often associated with the variation on seasonality, weather, and climatic conditions (Richards and Grabow 2003). In this study, in order to avoid the effect of seasonality, the data set used for comparison included January 1 to August 9, 2010, for ongoing BMPs and January 1 to August 9, 2011, for post-BMPs. Implementation of additional agricultural BMPs, such as appropriate drainage water management strategies or the restriction of cattle access to streams (LaWare and Rifai 2006; Adeuya et al. 2012; Jaynes 2012), will help further reduction of sediment, nutrient, and fecal coliform pollution in the watershed.

Land Use Effects on Surface Water Quality. A comparison of the four exclusive sites (sites 3, 4, 6, and 7) showed site 6, on average, with significantly higher fecal coliform counts and TKN concentration compared to the rest of the sites (table 4). Average fecal coliform counts for site 6 (561,597 MPN per $100 \mathrm{~mL}$ ) was 5.2 times higher than that for site $3(107,727 \mathrm{MPN}$ per $100 \mathrm{~mL}$ ), 7.64 times higher than that for site $4(73,465 \mathrm{MPN}$ per $100 \mathrm{~mL})$, and 4.56 times higher than that for site $7 \quad(122,961$ MPN per $100 \mathrm{~mL}$ ). While fecal coliform bacteria can be the result of feces from humans, domestic animals, wild birds, or any other warm-blooded animals (LaWare and Rifai 2006), elevated fecal coliform counts in surface water bodies are usually associated with the failing septic systems, sewage discharge from municipal treatment plants, sanitary sewer overflows, other inappropriate human discharges, and runoff from pasturelands (Pitt 1998; Schueler and Holland 2000; Hill et al. 2005; Mallin 2013). Mallin et al. (2000) reported significantly strong correlation between fecal coliform abundance and the proportion of developed land within the watershed and human population. Higher TKN values are also associated with wastewater disposal (Mallin 2013). In this study, site 6 , which had the largest proportion of developed area (0.113) among the seven sites, included $28.7 \%$ of the rural septic systems repaired or installed, the highest percentage of repaired or installed septic systems among the seven sites in the watershed. Therefore, although there would have been some contribution from agricultural lands (table 1) and natural sources to fecal coliform pollution, these results suggest that the major sources of fecal coliform pollution in this watershed were anthropogenic, resulting from the developed areas and the failed septic systems.

Results from the comparison of four exclusive sites also showed that site 4 , on average, had significantly lower DO value and TDS 
Figure 7

Average monthly (a) turbidity, (b) conductivity, (c) pH, (d) total solids (TS), (e) total dissolved solids (TDS), (f) total suspended solids (TSS), (g) total Kjeldahl nitrogen (TKN), (h) five-day biological oxygen demand $\left(\mathrm{BOD}_{5}\right.$, (i) nitrate/nitrite- $\mathrm{N}\left(\mathrm{NO}_{3} / \mathrm{NO}_{2}-\mathrm{N}\right)$, (j) dissolved oxygen (DO), (k) surface water temperature, (l) soluble reactive phosphate (SRP), (m) total phosphorus (TP), ), (n) chloride, (o) fluoride, (p) sulfate and (q) fecal coliform counts for the Coulee Baton watershed, Louisiana (September of 2009 to August of 2011).

(a)

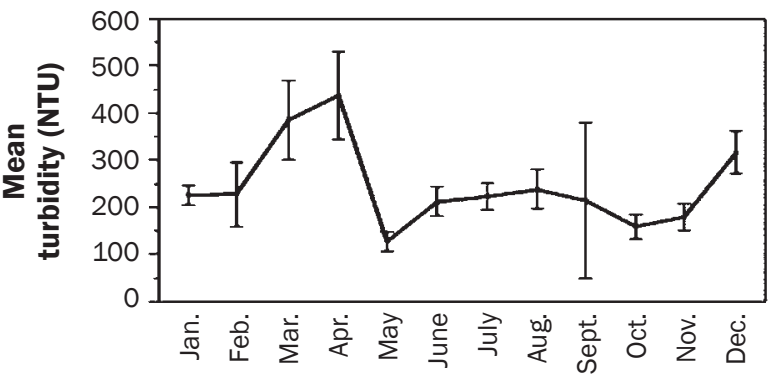

(c)

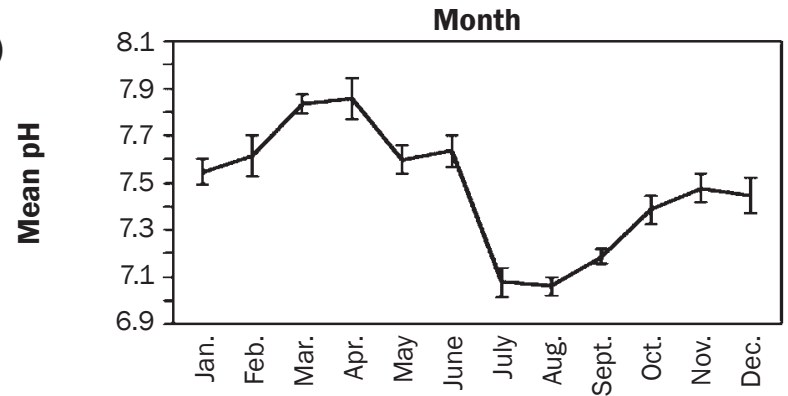

(e)

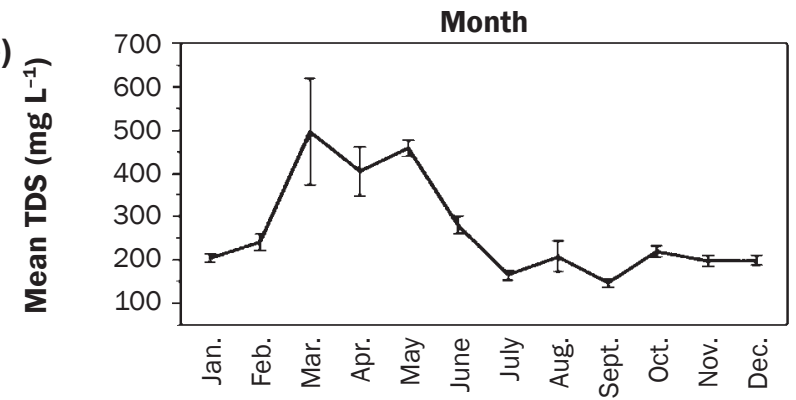

(g)

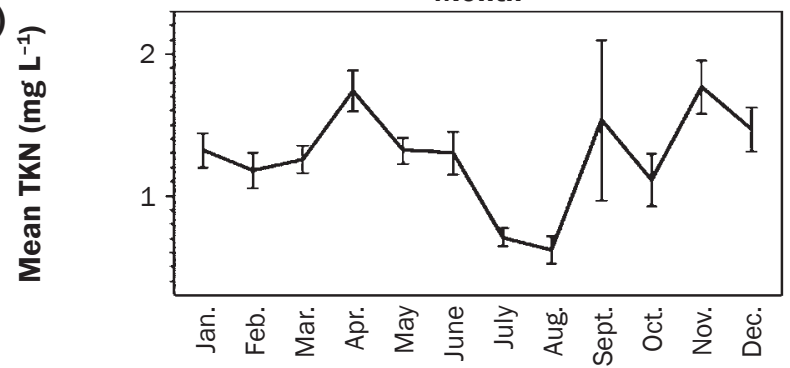

(i)

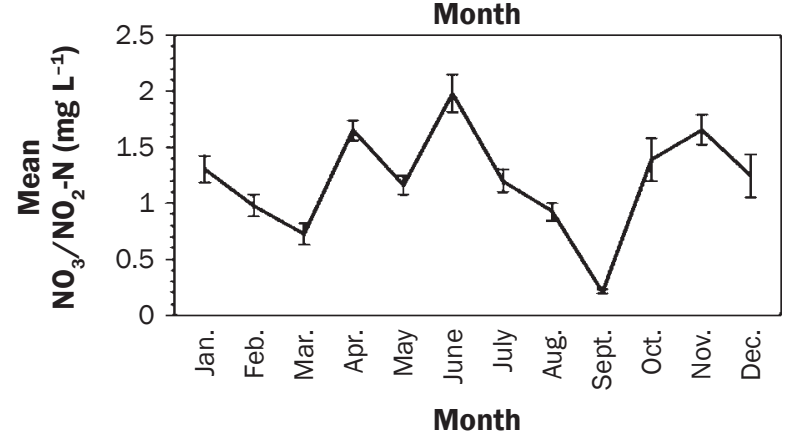

(b)

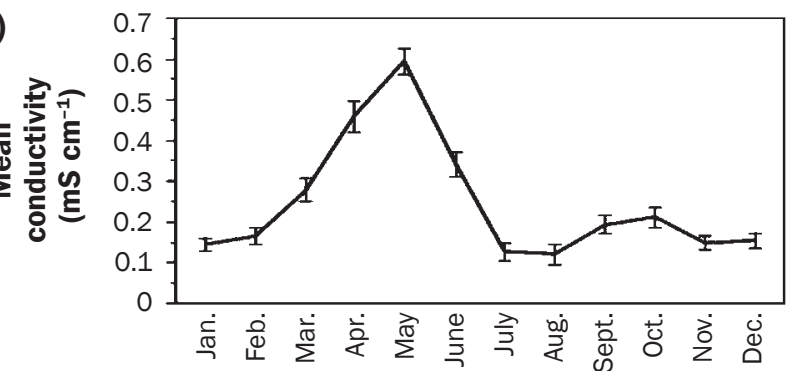

(d)

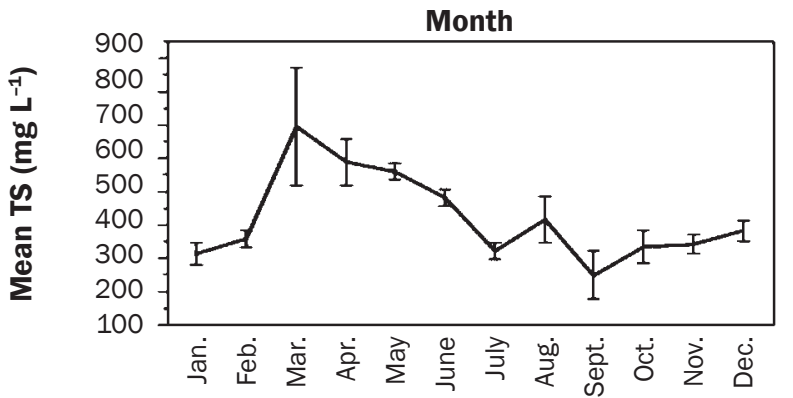

(f)

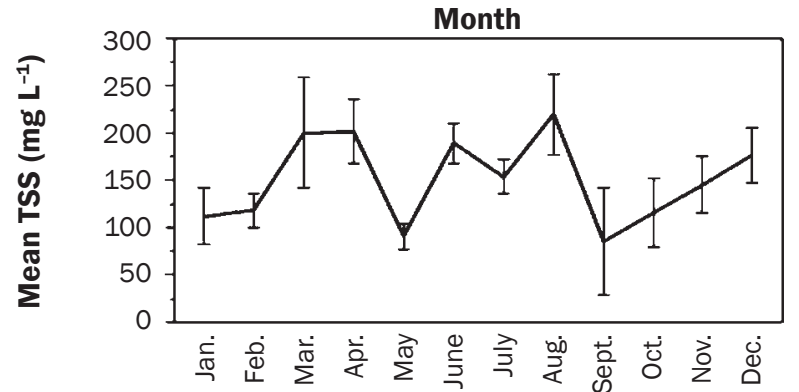

(h)

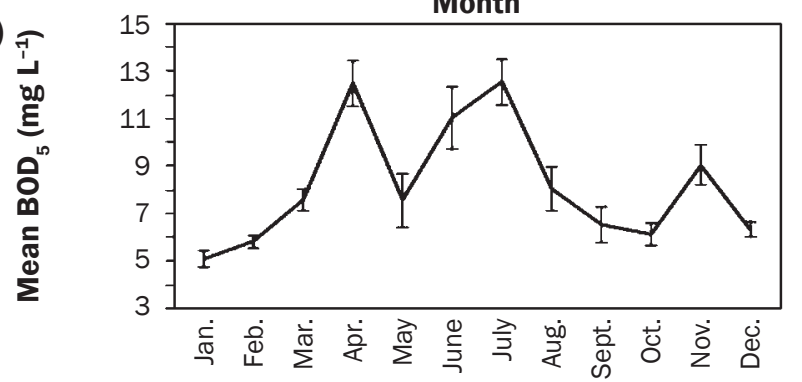

(j)

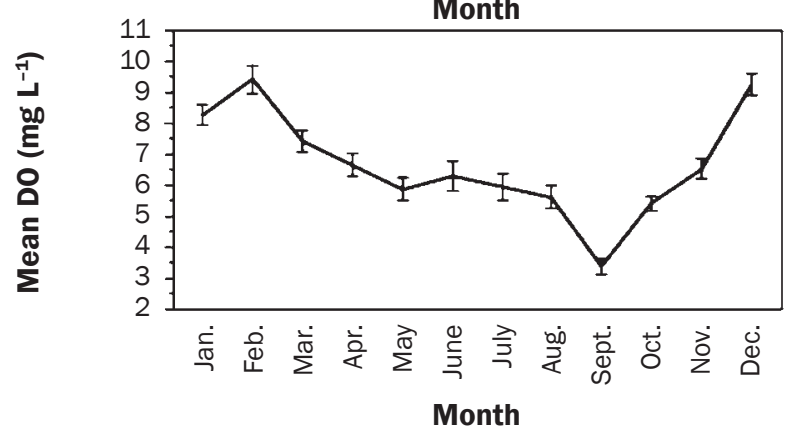




\section{Figure 7 Continued}

(k)

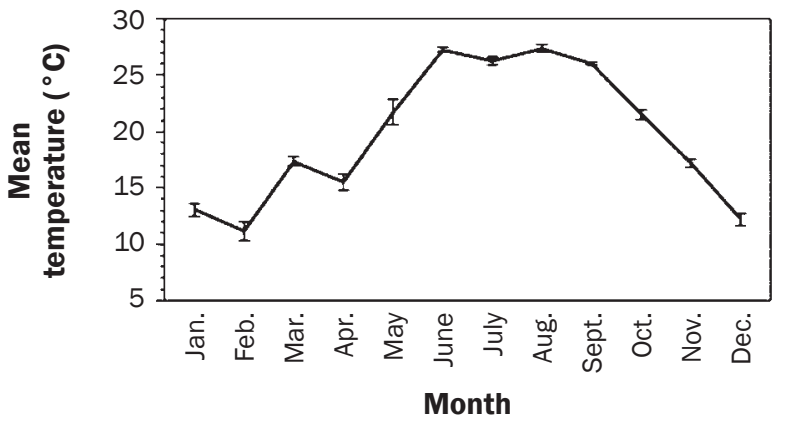

(m)

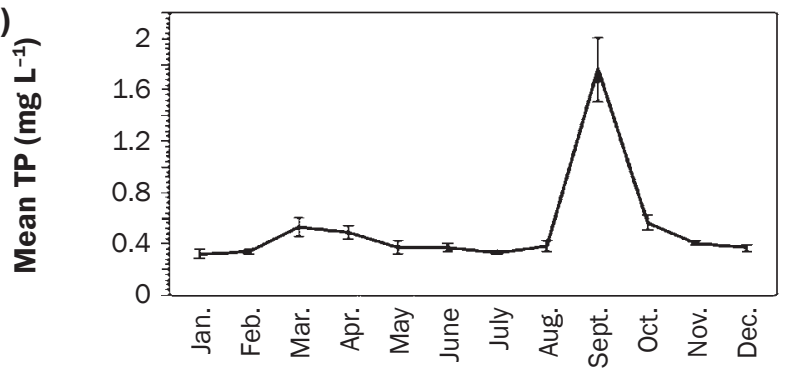

(o)

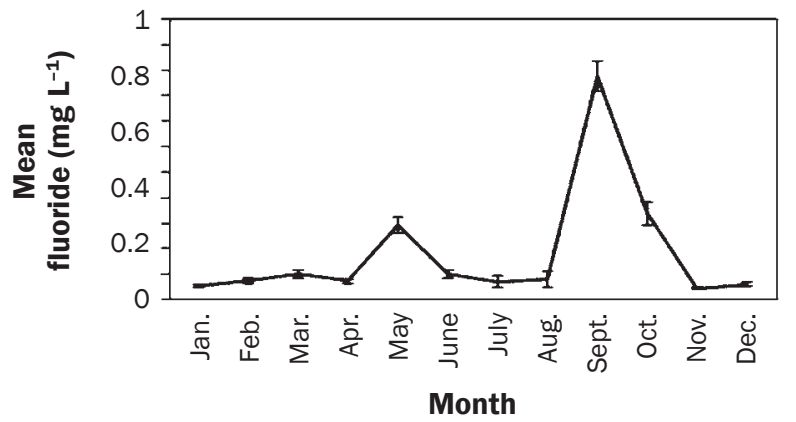

(q)

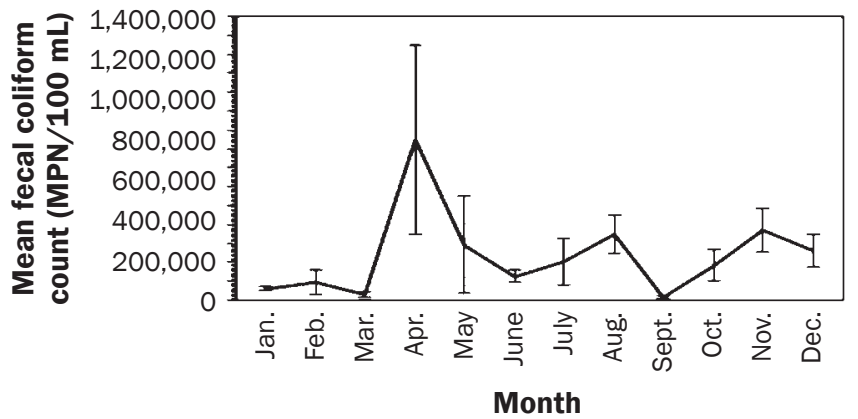

(I)

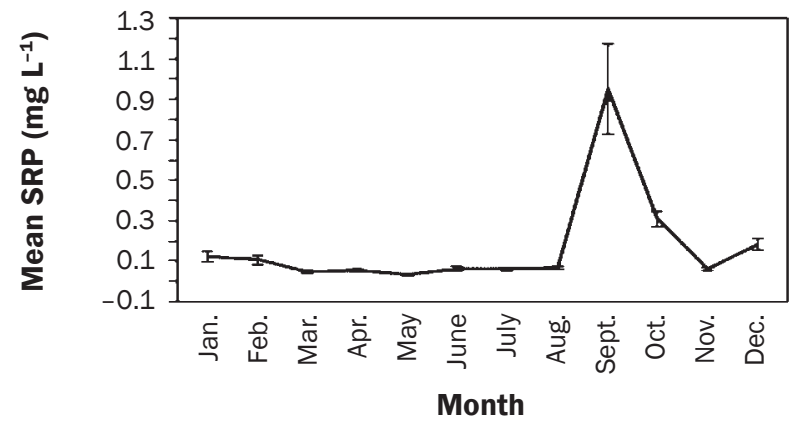

(n)

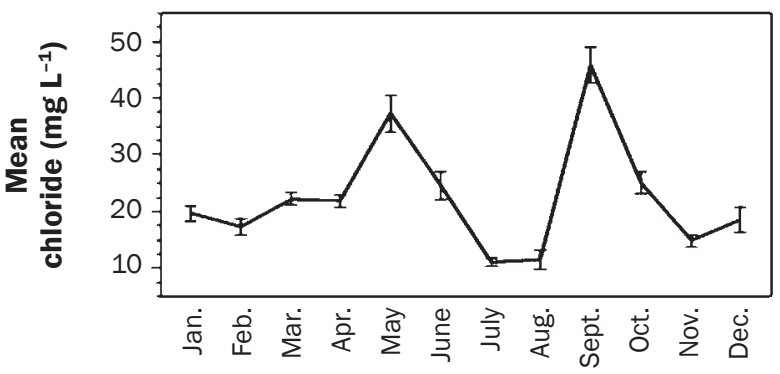

Month

(p)

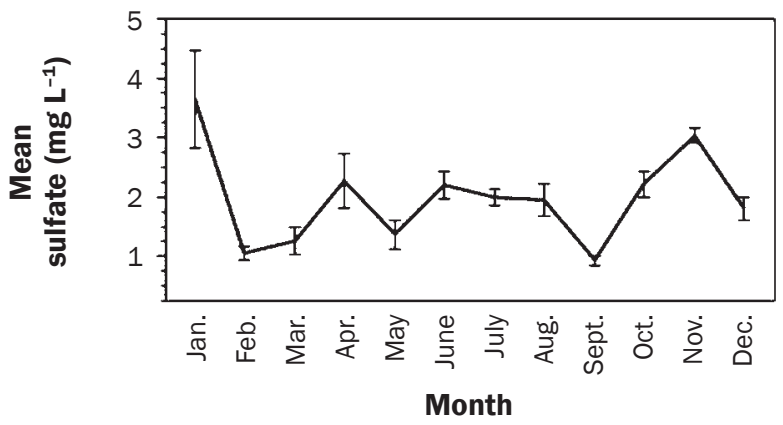

concentration (table 4). These lower DO and TDS values at site 4 were due to more of the site conditions than the land use types. Site 4 , on average, had less than $0.3 \mathrm{~m}(0.98 \mathrm{ft})$ water depth during the sampling events (figure 4), and we frequently observed stagnant water at this site during sampling. Stagnant water in a channel favors the accumulation of organic matter, and the decomposition of organic matter by microbes results in the depletion of DO in the waterbody. In addition, stagnant water also favors less diffusion of free $\mathrm{O}_{2}$ from atmosphere into the waterbody. Poudel et al. (2013) reported higher DO levels for fast moving waters upstream compared to the one with slow moving downstream in a nearby agricultural watershed in southwestern Louisiana.

\section{Summary and Conclusions}

Substantial spatial and monthly variability on surface water quality exists in the Coulee Baton watershed. As compared to the tributary sites, the main channel sites had significantly higher values of suspended solids, TDS, and turbidity. On the other hand, the tributary sites had significantly higher concentrations of TKN compared to the main channel sites. Coinciding with agricultural activities in the watershed, fluxes of sediments and nutrients start early spring and continue to occur throughout the summer and the fall. Implementation of BMPs in agricultural lands and the repair or replace- 


\section{Table 3}

A comparison of the surface water quality (temperature, conductivity, $\mathrm{pH}$, turbidity, dissolved oxygen [DO], total suspended solids [TSS], total dissolved solids [TDS], total solids [TS], nitrate/nitrite- $\mathrm{N}\left[\mathrm{NO}_{3} / \mathrm{NO}_{2}-\mathrm{N}\right]$, five-day biological oxygen demand $\left[\mathrm{BOD}_{5}\right]$, chloride, fluoride, sulfate [ $\mathrm{SO}_{4}$ ], soluble reactive phosphate [SRP], total phosphorus [TP], total Kjeldahl nitrogen [TKN], and fecal coliform counts) of the Coulee Baton watershed between ongoing best management practices (BMPs) (January 1, 2010, to August 9, 2010) and the post-BMPs (January 1, 2011, to August 9, 2011) conditions among the four exclusive sites (sites 3, 4, 6, and 7 ) in Coulee Baton watershed in southwestern Louisiana (September of 2009 to August of 2011).

\begin{tabular}{|c|c|c|c|c|}
\hline \multirow[b]{2}{*}{ Parameter } & \multicolumn{2}{|c|}{ Ongoing BMPs } & \multicolumn{2}{|c|}{ Post-BMPs } \\
\hline & $n$ & Mean & $n$ & Mean \\
\hline Temperature $\left({ }^{\circ} \mathrm{C}\right)$ & 55 & $22.40( \pm 0.95) \dagger * * *$ & 103 & $17.43( \pm 0.66) * * *$ \\
\hline Conductivity $\left(\mathrm{mS} \mathrm{cm}^{-1}\right)$ & 55 & $0.164( \pm 0.02) * * *$ & 103 & $0.348( \pm 0.024) * * *$ \\
\hline $\mathrm{pH}$ & 55 & $7.38( \pm 0.06) * *$ & 103 & $7.60( \pm 0.04) * *$ \\
\hline Turbidity (NTU) & 55 & $204.15( \pm 25.81) n s$ & 103 & $173.02( \pm 20.59) \mathrm{ns}$ \\
\hline $\mathrm{DO}\left(\mathrm{mg} \mathrm{L}^{-1}\right)$ & 55 & $7.05( \pm 0.41) \mathrm{ns}$ & 103 & $6.92( \pm 0.27) n s$ \\
\hline TSS (mg L-1) & 55 & $216.36( \pm 26.82)^{* * *}$ & 103 & $94.61( \pm 10.08) * * *$ \\
\hline TDS (mg L-1) & 55 & $201.43( \pm 14.14)^{* * *}$ & 103 & $286.34( \pm 13.36)^{* * *}$ \\
\hline TS $\left(\mathrm{mg} \mathrm{L}^{-1}\right)$ & 55 & $426.87( \pm 31.55) \mathrm{ns}$ & 103 & $376.01( \pm 17.29) \mathrm{ns}$ \\
\hline $\mathrm{NO}_{3} / \mathrm{NO}_{2}-\mathrm{N}\left(\mathrm{mg} \mathrm{L}^{-1}\right)$ & 55 & $1.479( \pm 0.124)^{* *}$ & 103 & $1.137( \pm 0.067)^{* *}$ \\
\hline $\mathrm{BOD}_{5}\left(\mathrm{mg} \mathrm{L}^{-1}\right)$ & 55 & $10.44( \pm 0.64)^{* *}$ & 103 & $7.58( \pm 0.57) * *$ \\
\hline Chloride (mg L-1) & 55 & $19.27( \pm 2.08) \mathrm{ns}$ & 103 & $23.28( \pm 1.47) \mathrm{ns}$ \\
\hline Fluoride $\left(\mathrm{mg} \mathrm{L}^{-1}\right)$ & 55 & $0.109( \pm 0.023) \mathrm{ns}$ & 103 & $0.101( \pm 0.013) \mathrm{ns}$ \\
\hline $\mathrm{SO}_{4}\left(\mathrm{mg} \mathrm{L}^{-1}\right)$ & 55 & $2.748( \pm 0.276)^{\star \star *}$ & 103 & $1.454( \pm 0.134) * * *$ \\
\hline $\mathrm{SRP}\left(\mathrm{mg} \mathrm{L}^{-1}\right)$ & 55 & $0.244( \pm 0.031) * * *$ & 103 & $0.042( \pm 0.003) * * *$ \\
\hline $\mathrm{TP}\left(\mathrm{mg} \mathrm{L}^{-1}\right)$ & 55 & $0.439( \pm 0.032) \mathrm{ns}$ & 103 & $0.388( \pm 0.028) \mathrm{ns}$ \\
\hline TKN (mg L-1) & 55 & $1.073( \pm 0.12)^{*}$ & 103 & $1.411( \pm 0.06)^{*}$ \\
\hline $\begin{array}{l}\text { Fecal coliform } \\
\text { (MPN per } 100 \mathrm{~mL} \text { ) }\end{array}$ & 55 & $305,207(110,000) \mathrm{ns}$ & 103 & $154,812( \pm 90,588) \mathrm{ns}$ \\
\hline
\end{tabular}

$* p<0.05 * * p<0.01 * * * p<0.001$

Note: Means followed by ns are not significantly different at 0.05 probability level by the two sample student's t-test with independent sample. MPN = most probable number. Numbers in parentheses are \pm standard error of mean. $n s=$ not significant.

ment of septic systems resulted in significant reduction of TSS, $\mathrm{NO}_{3} / \mathrm{NO}_{2}-\mathrm{N}, \mathrm{SRP}, \mathrm{SO}_{4}$, and the $\mathrm{BOD}_{5}$ levels in the Coulee Baton surface water. However, the levels of TDS, conductivity, and TKN were significantly higher even after the implementation of BMPs. Developed land use types and failed septic systems impacted fecal coliform and N pollution in the watershed. In order to control nonpoint source pollution effectively, appropriate BMPs should be implemented by considering the occurrence, movement, and the seasonality of the nonpoint source pollutants, land use types, and the conditions of rural septic systems.

\section{Acknowledgements}

The author would like to acknowledge the Louisiana Department of Environmental Quality (LDEQ) and the US Environmental Protection Agency (USEPA) Region VI for funding this project through the 319 grant program. Thanks to Cortez Rankin, Reggie Coleman, Max Forbes, Christy Rando, and Stephanie Morel at LDEQ, Baton Rouge,
Louisiana, for their support in this project. Also, many thanks to Brian Kibbe, Will Bernard, and Colette Anzalone at the University of Louisiana at Lafayette, Lafayette, Louisiana, for their help in field work, field instrumentation, and water quality sample collection. The support from Louisiana State University AgCenter (LSU AgCenter) by lending ISCO samplers and flowmeters is much appreciated. Special thanks to the Vermilion Soil and Water Conservation District (VSWCD), Abbeville, Louisiana, for leading this initiative for building a collaborative partnerships for the Coulee Baton watershed. Similarly, special thanks to Ernest Girouard at VSWCD Abbeville, Louisiana, and LSU AgCenter, Crowley, Louisiana, Sherill Sagrera and Mitzi Dohrman at VSWCD, Abbeville, Louisiana, Dexter Sapp and Robert Capezza at USDA NRCS, Alexandria, Louisiana, and Acadiana RC\&D, Louisiana, for their help and participation in various project meetings. Active participations of local communities, governmental agencies, and other stakeholders in the project planning meetings are highly appreciated. The author would like to thank the anonymous reviewers for their excellent and highly valuable comments and suggestions to improve the quality of this research paper.

\section{References}

Adeuya, R., N. Utt, J. Frankenberger, L. Bowling, E. Kladivko, S. Brouder, and B. Carter. 2012. Impacts of drainage water management on subsurface drain flow, nitrate concentration, and nitrate loads in Indiana. Journal of Soil and Water Conservation 67(6):474-484, doi:10.2489/jswc.67.6.474.

Andraski, T.W., and L.G. Bundy. 2003. Relationships between phosphorus levels in soil and in runoff from corn production systems, Journal of Environmental Quality 32:310-316.

Bollich, P.K., and S.E. Feagley. 1994. A comparison of water-seeded rice management systems: Potential improvements in water quality, Proc. Of the 1994 Southern Conservation Tillage Conference for Sustainable Agriculture, 64-69, Columbia, South Carolina. USDA Agricultural Research Service Coastal Plains Soil, Water, and Plant Research Center.

Chase, E., J. Hunting, C. Staley, and V.J. Harwood. 2012. Microbial source tracking to identify human and ruminant sources of fecal pollution in an ephemeral Florida river. Journal of Applied Microbiology 113:1396-1406.

Clesceri L.S., A.E. Greenberg, and A.D. Eaton. 1998. Standard Methods for the Examination of Water and Wastewater, 20th ed., Washington, DC: American Public Health Association.

Cockerill, K., H. Passel, and V. Tidwell. 2006. Co-operative modeling: Building bridges between science and the public. Journal of the American Water Resources Association 42(2):457-471.

Collick, A.S., Z.M. Easton, F.A. Montalto, B. Gao, Y. Kim, L. Day, and T.S. Steenhuis. 2006. Hydrological evaluation of septic disposal field design in sloping terrains. Journal of Environmental Engineering 132(10):1289-1297.

Demcheck, D.K., R.W.Tollett, S.V. Mize, S.C. Skrobialowski, R.B. Fendick, Jr., C.M. Swarzenski, and S. Porter. 2004. Water quality in the Acadian-Pontchartrain drainages, Louisiana and Mississippi, 1999-2001. Reston, VA: US Geological Survey Circular 1232, $47 \mathrm{p}$

Hamilton, P.A., and T.L. Miller. 2002. Lessons from the national water-quality assessment. Journal of Soil and Water Conservation 57(1):16A-21A.

Hill, D.D., W.E. Owens, and P.B. Tchounwou. 2005. Comparative assessment of the physico-chemical and bacteriological qualities of selected streams in Louisiana. International Journal of Environmental Research and Public Health 2(1):94-100.

Hill, D.D., W.E. Owens, and P.B. Tchounwou. 2006. The impact of rainfall on fecal coliform bacteria in Bayou Dorcheat (North Louisiana). International Journal of Environmental Research and Public Health 3(1):114-117.

Huner, J.V., C.W. Jeske, and W. Norling. 2002. Managing agricultural wetlands for waterbirds in the Coastal Regions of Louisiana, U.S.A. Waterbirds 25(2):66-78. 


\section{Figure 8}

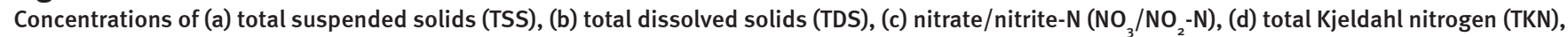
(e) soluble reactive phosphate (SRP), (f) five-day biological oxygen demand (BOD), (g) sulfate, (h) conductivity, (i) pH, and (j) surface water temperature for the four exclusive sites (sites 3, 4, 6, and 7) in the Coulee Baton watershed, Louisiana (September of 2009 to August of 2011).

(a)

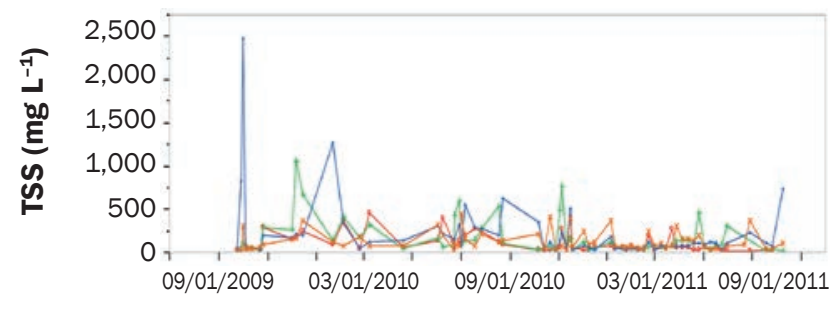

Date

(c)

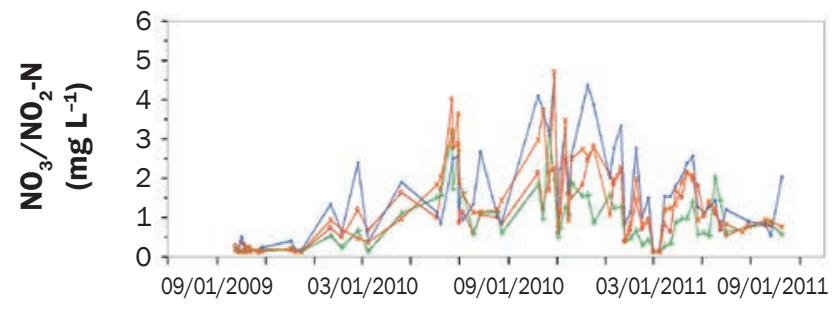

Date

(e)

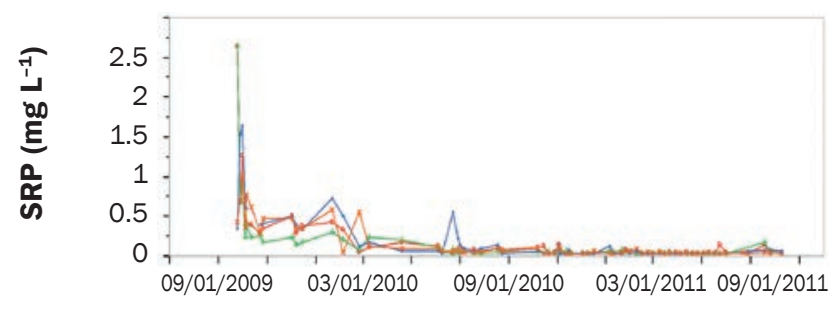

Date

(g)

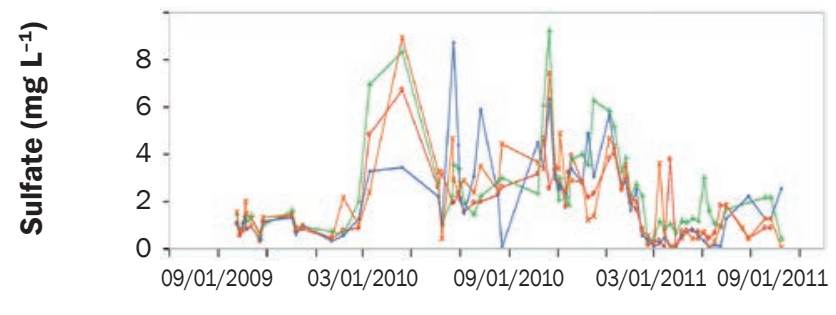

Date

(i)

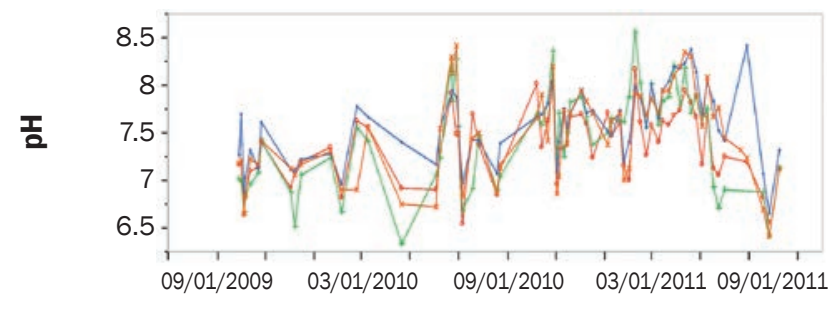

Date

Legend - Site $3-$ Site $4-$ Site $6-$ Site 7 (b)

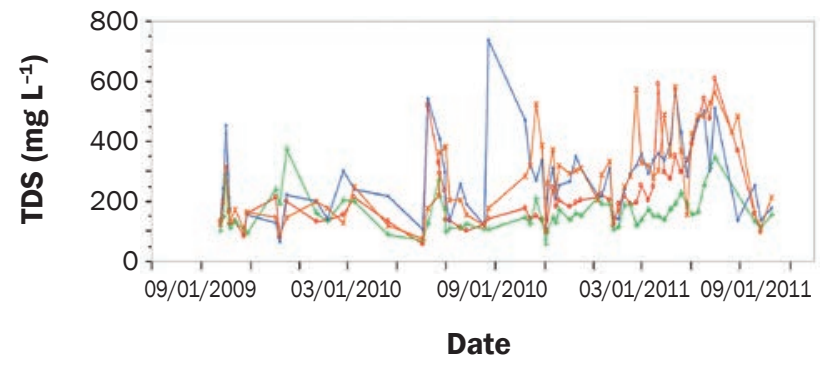

(d)

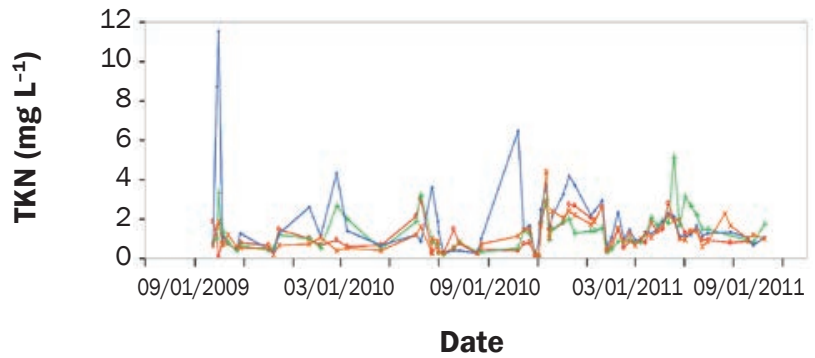

(f)

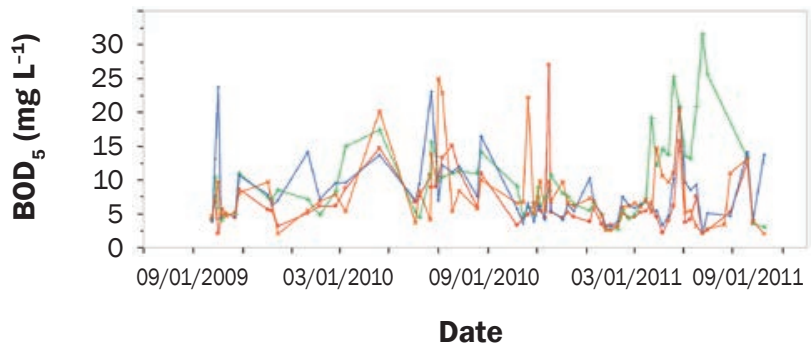

(h)

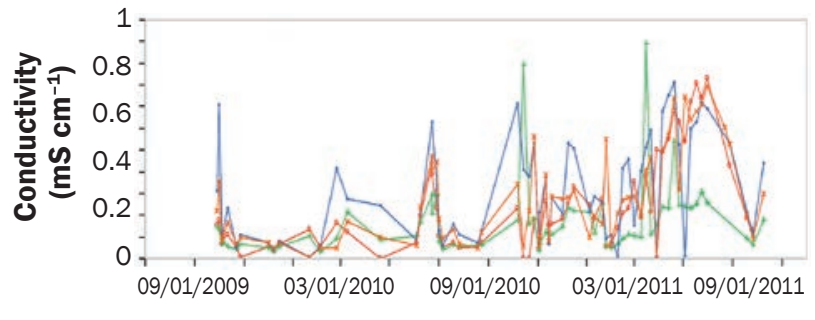

Date

(j)

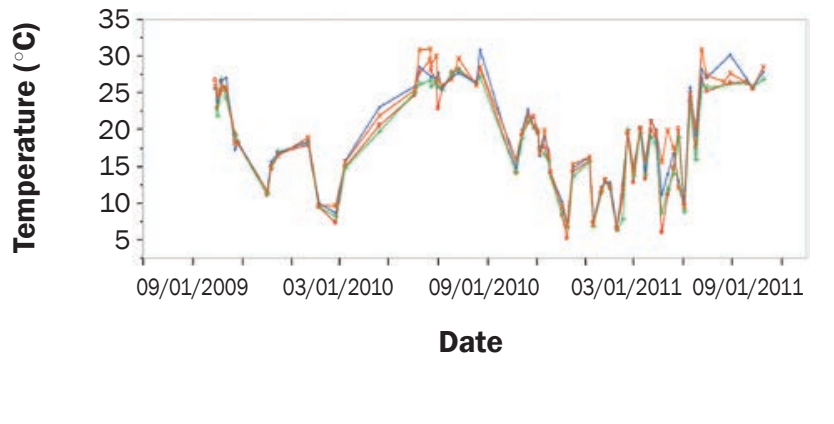


Table 4

Average and range of dissolved oxygen (DO), surface water temperature, turbidity, conductivity, pH, total suspended solids (TSS), total dissolved

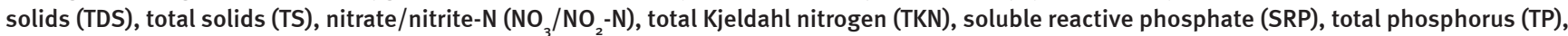
five-day biological oxygen demand $\left(\mathrm{BOD}_{5}\right)$, chloride, fluoride, sulfate and fecal coliforms for the four exclusive sites (sites 3, 4, 6, and 7) of the Coulee Baton watershed, Louisiana (September of 2009 to August of 2011).

\begin{tabular}{|c|c|c|c|c|}
\hline Parameter & Site 3 & Site 4 & Site 6 & Site 7 \\
\hline \multicolumn{5}{|l|}{$\mathrm{DO}\left(\mathrm{mg} \mathrm{L}^{-1}\right)$} \\
\hline$n$ & 63 & 63 & 62 & 65 \\
\hline Range & 3.4 to 12.49 & 1.3 to 12.98 & 1.18 to 13.7 & 1.2 to 14.0 \\
\hline \multicolumn{5}{|l|}{$\operatorname{Temp}\left({ }^{\circ} \mathrm{C}\right)$} \\
\hline$n$ & 63 & 63 & 63 & 65 \\
\hline \multicolumn{5}{|c|}{ Turbidity (NTU) } \\
\hline$n$ & 63 & 63 & 63 & 65 \\
\hline Mean & $166.2( \pm 25.1) \mathrm{ns}$ & $192.8( \pm 36.1) \mathrm{ns}$ & $213.4( \pm 29.6) n s$ & 231.1( \pm 31.6$) n s$ \\
\hline Range & 7.8 to $1,076.6$ & 6.21 to $1,703.2$ & 10 to $1,206.3$ & 6 to $1,259.8$ \\
\hline \multicolumn{5}{|c|}{ Conductivity $\left(\mathrm{mS} \mathrm{cm}^{-1}\right)$} \\
\hline \multicolumn{5}{|l|}{$\mathrm{pH}$} \\
\hline$n$ & 63 & 63 & 63 & 65 \\
\hline Mean & $7.35( \pm 0.04) b$ & $7.42( \pm 0.06) a b$ & $7.57( \pm 0.04) a$ & $7.48( \pm 0.06) a b$ \\
\hline Range & 6.54 to 8.17 & 6.34 to 8.56 & 6.65 to 8.41 & 6.41 to 8.42 \\
\hline \multicolumn{5}{|c|}{ TSS (mg L-1) } \\
\hline$n$ & 63 & 64 & 63 & 66 \\
\hline Mean & $100( \pm 12.8) b$ & $165( \pm 25.5) a b$ & $216( \pm 45.8) a$ & $129( \pm 13.7) a b$ \\
\hline Range & 10 to 462 & 20 to 1,055 & 14 to 2,481 & 11 to 443 \\
\hline \multicolumn{5}{|c|}{ TDS (mg L-1) } \\
\hline$n$ & 63 & 64 & 63 & 66 \\
\hline$n$ & 64 & 64 & 63 & 66 \\
\hline Mean & $1.17( \pm 0.11) a b$ & $0.91( \pm 0.09) b$ & $1.60( \pm 0.15) a$ & $1.33( \pm 0.13) a b$ \\
\hline Range & 0.13 to 4.01 & 0.13 to 3.22 & 0.13 to 4.56 & 0.13 to 4.70 \\
\hline \multicolumn{5}{|c|}{ TKN (mg L-1) } \\
\hline$n$ & 64 & 64 & 63 & 66 \\
\hline Mean & $1.13( \pm 0.09) b$ & $1.31( \pm 0.11) b$ & $1.86( \pm 0.24) a$ & $1.16( \pm 0.09) b$ \\
\hline Range & 0.08 to 3.0 & 0.08 to 5.15 & 0.18 to 11.51 & 0.16 to 4.38 \\
\hline \multicolumn{5}{|c|}{$\mathrm{SRP}\left(\mathrm{mg} \mathrm{L}^{-1}\right)$} \\
\hline$n$ & 64 & 64 & 63 & 66 \\
\hline Mean & $0.18( \pm 0.05) \mathrm{ns}$ & $0.15( \pm 0.04) \mathrm{ns}$ & $0.18( \pm 0.04) \mathrm{ns}$ & $0.15( \pm 0.03) \mathrm{ns}$ \\
\hline Range & 0.03 to 2.63 & 0.03 to 2.64 & 0.03 to 1.64 & 0.03 to 1.01 \\
\hline \multicolumn{5}{|l|}{$\mathrm{TP}\left(\mathrm{mg} \mathrm{L}^{-1}\right)$} \\
\hline$n$ & 64 & 64 & 63 & 66 \\
\hline Mean & $0.38( \pm 0.03) \mathrm{ns}$ & $0.53( \pm 0.04) \mathrm{ns}$ & $0.48( \pm 0.06) \mathrm{ns}$ & $0.50( \pm 0.05) \mathrm{ns}$ \\
\hline Range & 0.10 to 1.61 & 0.14 to 1.56 & 0.10 to 3.03 & 0.12 to 2.68 \\
\hline
\end{tabular}




\section{Table 4 continued}

\begin{tabular}{|c|c|c|c|c|}
\hline Parameter & Site 3 & Site 4 & Site 6 & Site 7 \\
\hline \multicolumn{5}{|c|}{$\mathrm{BOD}_{5}\left(\mathrm{mg} \mathrm{L}^{-1}\right)$} \\
\hline$n$ & 64 & 64 & 63 & 66 \\
\hline Range & 2 to 27 & 2.7 to 31.5 & 2 to 23.8 & 2 to 24.9 \\
\hline \multicolumn{5}{|c|}{ Chloride $\left(\mathrm{mg} \mathrm{L}^{-1}\right)$} \\
\hline$n$ & 64 & 64 & 63 & 66 \\
\hline Range & 4.68 to 96.79 & 0.32 to 58.12 & 5.07 to 100.31 & 4.93 to 76.37 \\
\hline \multicolumn{5}{|c|}{ Fluoride $\left(\mathrm{mg} \mathrm{L}^{-1}\right)$} \\
\hline$n$ & 64 & 64 & 63 & 66 \\
\hline Mean & $0.16( \pm 0.03) \mathrm{ns}$ & $0.16( \pm 0.03) \mathrm{ns}$ & $0.14( \pm 0.02) \mathrm{ns}$ & $0.14( \pm 0.03) \mathrm{ns}$ \\
\hline Range & 0.04 to 1.04 & 0.04 to 1.06 & 0.04 to 0.8 & 0.04 to 0.93 \\
\hline \multicolumn{5}{|c|}{ Sulfate (mg L-1) } \\
\hline \multicolumn{5}{|c|}{ Fecal coliforms } \\
\hline \multicolumn{5}{|c|}{ (MPN per $100 \mathrm{~mL}$ ) } \\
\hline$n$ & 62 & 63 & 63 & 65 \\
\hline \multirow[t]{2}{*}{ Mean } & 107,727 & 73,465 & 561,597 & 122,961 \\
\hline & $( \pm 28,604) \mathrm{b}$ & $( \pm 17,207) \mathrm{b}$ & $( \pm 188,042) \mathrm{a}$ & $( \pm 38,846) \mathrm{b}$ \\
\hline Range & 400 to $1.3 \mathrm{M}$ & 400 to $0.7 \mathrm{M}$ & 800 to $9 \mathrm{M}$ & 400 to $1.3 \mathrm{M}$ \\
\hline
\end{tabular}

Notes: $n=$ sample size. $n s$ = not significant. Numbers given in parentheses are the standard error of mean. Values across the row with different letters are significantly different at 0.05 probability level by Tukey-Kramer HSD test.

Jaynes, D.B. 2012. Changes on yield and nitrate losses from using drainage water management in central Iowa, United States. Journal of Soil and Water Conservation 67(6):485-494, doi:10.2489/jswc.67.6.485.

Johnston, M.A., D.E. Porter, G.I. Scott, W.E. Rhodes, and L.F. Webster. 2010. Isolation of fecal coliform bacteria from the American alligator (Alligator mississippiensis). Journal of Applied Microbiology 108(3):965-973.

Kirschner, A.K.T., T. C. Zechmeister, G.G. Kavka, C. Beiwl, A. Herzig, R.L. Mach, and A.H. Farnleitner. 2004. Integral strategy for evaluation of fecal indicator performance in bird-influenced saline inland waters. Applied and Environmental Microbiology 70(12):7396-7403.

Kröger, R., M. Perez, S. Walker, and A. Sharpley. 2012a. Review of best management practice reduction efficiencies in the lower Mississippi Alluvial Valley. Journal of Soil and Water Conservation 67(6):556-553, doi:10.2489/jswc.67.6.556.

Kröger, R., M.T. Moore, K.W. Thornton, J.L. Farris, J.D. Prevost, and S.C. Pierce. 2012b. Tiered on-theground implementation projects for Gulf of Mexico water quality improvements. Journal of Soil and Water Conservation 67(4):94A-99A, doi:10.2489/ jswc.67.4.94A.

Lafrance, P., E. Caron, and C. Bernard. 2013. Temporal evolution of atrazine, metolachlor, and deethylatrazine concentrations in runoff from grass filter strips in a four- season study. Journal of Soil and Water Conservation 68(5):419-427, doi:10.2489/jswc.68.5.419.

LaWare, P., and H.S. Rifai. 2006. Modeling fecal coliform contamination in the Rio Grande. Journal of American Water Resources Association 42(2):337-356.

LDEQ (Louisiana Department of Environmental Quality) 2000. Louisiana's Nonpoint Source Management Plan, Volume 6 State of Louisiana Water Quality Management Plan. Baton Rouge, LA: Office of Environmental Assessment, Louisiana Department of Environmental Quality.

LDEQ. 2014. Title 33: Environmental Quality, Part IX, Water Quality, Subpart 1 Water Pollution Control http://www.deq.louisiana.gov/portal/Portals/0/ planning/regs/title33/33v09-201404.pdf .

Lemly, A.D. 2004. Aquatic selenium pollution is a global environmental safety issue. Ecotoxicology and Environmental Safety 59:44-56.

Lowrance, R., S. Dabney, and R. Schultz. 2002. Improving water and soil quality with conservation buffers. Journal of Soil and Water Conservation 57(2):36A-43A.

LSU (Louisiana State University) AgCenter. 1999. Crawfish Production Manual. Baton Rouge, LA: LSU AgCenter, Louisiana State University.

LSU AgCenter. 2000. Rice production Best Management Practices (BMPs). Baton Rouge, LA: LSU AgCenter, Louisiana State University.
LSU AgCenter. 2012. Louisiana Conservation Tillage Handbook. Baton Rouge, LA: LSU AgCenter, Louisiana State University.

LSU AgCenter. 2014. Louisiana Rice Production Handbook. Baton Rouge, LA: LSU AgCenter, Louisiana State University.

Mallin, M.A., K.E. Williams, E.C. Esham, and R.P. Lowe. 2000. Effect of human development on bacteriological water quality in coastal watersheds. Ecological Applications 10(4):1047-1056.

Mallin, M.A. 2013. Septic systems in the coastal environment: Multiple water quality problems in many areas. In Monitoring water quality: Pollution assessment, analysis, and remediation, ed. S. Ahuja, 81-102. Cambridge, MA: Elsevier.

Mueller-Warrant, G.W., S.M. Griffith, G.W. Whittaker, G.M. Banowetz, W.F. Pfender, T.S. Garcia, and G.R. Giannico. 2012. Impact of land use patterns and agricultural practices on water quality in the Calapooia River Basin of western Oregon. Journal of Soil and Water Conservation 67(3):183-201, doi:10.2489/ jswc.67.3.183.

Napier, T.L., and T. Bridges. 2002. Adoption of conservation production systems in two Ohio watersheds: A comparative study. Journal of Soil and Water Conservation 57(4):229-235

Neal, C.W.M., and A.M. Anders. 2015. Suspended sediment supply dominated by bank erosion in a low-gradient agricultural watershed, Wildcat Slough, Fisher, Illinois, 
United States. Journal of Soil and Water Conservation 70(3):145-155, doi:10.2489/jswc.70.3.145.

Orellana, F.X., and R.P. Romaire. 2007. Potential effluent quality from commercial crawfish ponds. North American Journal of Aquaculture 69(2):166-173.

Osmond, D., D. Meals, D. Hoag, M. Arabi, A. Luloff, G. Jennings, M. McFarland, J. Spooner, A. Sharpley, and D. Line. 2012. Improving conservation practices programming to protect water quality in agricultural watersheds: Lessons learned from the National Institute of Food and Agriculture-Conservation Effects Assessment Project. Journal of Soil and Water Conservation 67(5):122A-127A, doi:10.2489/ jswc.67.5.122A.

Pitt, R. 1998. Epidemiology and Stormwater Management. In Stormwater Quality Management. New York: CRC/Lewis Publishers.

Poudel, D.D. 2006. Challenges for improving surface water quality in an agricultural watershed in Louisiana. In Coastal Environment and Water Quality, Proceedings of the AIH 25th Anniversary Meeting \& International Conference, Challenges in Coastal Hydrology and Water Quality, Water Resources Publications, Highlands Ranch, CO, eds.Y.J. Xu and V.P. Singh, 251-261.

Poudel, D.D., and C.Y. Jeong. 2009. Manual composite sampling in edge-of-field surface runoff for assessing nonpoint source pollution from agricultural lands and residential areas. Journal of Soil and Water Conservation 64(5):324-335, doi:10.2489/jswc.64.5.324.

Poudel, D.D., C.Y. Jeong, and A. DeRamus. 2010. Surface run-off water quality from agricultural lands and residential areas. Outlook on Agriculture 39(2):95-105.

Poudel, D.D, T. Lee, R. Srinivasan, K. Abbaspour, and C.Y. Jeong. 2013. Assessment of seasonal and spatial variation of surface water quality, identification of factors associated with water quality variability, and the modeling of critical nonpoint source pollution areas in an agricultural watershed. Journal of Soil and Water Conservation 68(3):155-171, doi:10.2489/ jswc.68.3.155.

Richards, R.P., and G.L. Grabow. 2003. Detecting reductions in sediment loads associated with Ohio's Conservation Reserve Enhancement Program. Journal of the American Water Resources Association 39(5):1261-1268.

SAS Institute Inc. 2009. JMP 8.0.2, Cary, NC, USA.

Schueler, T.R., and H.K. Holland. 2000. Microbes and urban watersheds: Concentrations, sources, and pathways. In The Practice of Watershed Protection. Ellicott City, MD: Center for Watershed Protection.

Selim, H.M., C.Y. Jeong, A.E. Arceneaux, and R.L. Bengtson. 2011. Watershed water quality: Effect of best management strategies. Louisiana Agriculture 54(4):14-15.

Skrobialowski, S.C., S.V. Mize, and D.K. Demcheck. 2004. Environmental setting, water quality, and ecological indicators of surface-water quality in the Mermentau River Basin, Southwestern Louisiana, 1998-2001.
Water-Resources Investigations Report 03-4185. Baton Rouge, LA: US Geological Survey.

Southwick, L.M., B.C. Grigg, T.S. Kornecki, and J.L. Fouss. 2002. Potential influence of sugarcane cultivation on estuarine water quality of Louisiana's Gulf Coast. Journal of Agriculture and Food Chemistry 50(15):4393-4399.

Schneeberger, C.L., M. O’Driscoll, C. Humphrey, K. Henry, N. Deal, K. Seiber, V.R. Hill, and M. Zarate-Bermudez. 2015. Fate and transport of enteric microbes from septic systems in a coastal watershed. Journal of Environmental Health 77(9):22-30.

Thomas, J.C. 2009. Analysis of dissolved selenium loading from surface water and groundwater to Sweitzer Lake, Colorado, 2006-07. US Geological Survey Scientific Investigations Report 2009-5048, 19 p. Reston, VA: US Geological Survey. http://pubs.usgs.gov/ sir/2009/5048/pdf/SIR09-5048.pdf.

Udawatta, R.P., P.P. Motavalli, H.E. Garrett, and J.J. Krstansky. 2006. Nitrogen losses in runoff from three adjacent agricultural watersheds with claypan soils. Agriculture, Ecosystems and Environment 117(1):39-48.

USDA NASS (National Agricultural Statistics Service). 2014. USDA National Agricultural Statistics Service Cropland Data Layer. http://nassgeodata.gmu.edu/ CropScape/.

USDA NRCS (Natural Resources Conservation Service). 2006. Coulee Baton Microwatershed Plan. Alexandria, LA: USDA NRCS. http://www.nrcs.usda.gov/Internet/ FSE_DOCUMENTS/nrcs141p2_015435.pdf.

USEPA 2002a. Onsite wastewater treatment systems manual. Report \#EPA/625/R-00/008. Washington, DC: Office of Water and Office of Research and Development, USEPA.

USEPA. 2002b. Wastewater Technology Fact Sheet: Bacterial Source Tracking, EPA 832-F-02-010. Washington, DC: Office of Water, USEPA. http://water.epa.gov/scitech/ wastetech/upload/2002_10_15_mtb_bacsortk.pdf.

USEPA. 2014. Basic Information about Fluoride in Drinking Water. http://water.epa.gov/drink/contaminants/ basicinformation/fluoride.cfm\#four.

Vergura, J., R. Jones, S. Pratt, and G. Keith. 2002a. PIMA: An alternative approach to watershed management. Stephenville, TX: Texas Institute of Applied Environmental Research (TiAR), Tarleton State University. http://tiaer.tarleton.edu/pdf/PR0203.pdf.

Vergura, J., R. Jones, and S. Pratt. 2002b. The Goose Branch Story: Planned Intervention at the Microwatershed Level, Texas Institute of Applied Environmental Research (TiAR). Stephenville, TX: Tarleton State University. http://tiaer.tarleton.edu/pdf/PR0202.pdf.

White, M.J., D.E. Storm, P.R. Busteed, S.H. Stoodley, and S.J. Phillips. 2009. Evaluating nonpoint source critical source area contributions at the watershed scale. Journal of Environmental Quality 38(4):1654-1663.

Whitlock, J.E., D.T. Jones, and V.J. Harwood. 2002. Identification of the sources of fecal coliforms in urban watershed using antibiotic resistance analysis. Water Research 36:4273-4282.

Yuan, Y., R.L. Bingner, F.D. Theurer, and S. Kolian. 2007. Water quality simulation of rice/crawfish field ponds within Annualized AGNPS. Applied Engineering in Agriculture 23(5):585-595.

Zhou, X., M.J. Helmers, H. Asbjornsen, R. Kolka, M.D. Tomer, and R.M. Cruse. 2014. Nutrient removal by prairie strips in agricultural landscapes. Journal of Soil and Water Conservation 69(1):54-64, doi:10.2489/ jswc.69.1.54. 